\title{
Fund Managers under Pressure: Rationale and Determinants of Secondary Buyouts
}

\author{
Sridhar Arcot* Zsuzsanna Fluck** José-Miguel Gaspar* Ulrich Hege***
}

May 17, 2013

\begin{abstract}
During the last decade an increasing fraction of PE exits have been secondary deals, in which one PE fund sells their portfolio company to another PE fund. On a comprehensive sample of 9,771 LBO deals in the U.S. and in 12 European countries from 1980 to 2010, this paper investigates to what extent secondary deals are outcomes of opportunistic behavior of the sponsor or adverse incentives of the PE contract. We report evidence that a secondary deal is significantly more likely if either the buyer fund is under pressure to invest or if the seller fund is under pressure to exit. We measure deal pressure by the closeness to the end of the lifecycle/investment period of a fund, by its degree of inactivity or unused funds and by its lack of reputation. Deal pressure also has an impact on deal valuation: Buyers under pressure pay relatively more for the secondary deals that they enter into, while sellers under pressure are willing to accept lower prices for their portfolio firms in secondary buyouts. The latter effect in dominated by the former suggesting that sellers have more bargaining power in secondary transactions.
\end{abstract}

JEL Classification: $\quad$ G35; G32

Keywords: $\quad$ leveraged buyouts; secondary buyouts; private equity; limited investment horizon.

The authors' affiliation are *ESSEC Business School, **University of Paris-Dauphine and Michigan State University, and ***HEC Paris. Corresponding author: José-Miguel Gaspar, ESSEC Business School, Avenue Bernard Hirsch, 95021 Cergy-Pontoise, France. Tel.: +33134433374. Fax: +33134433212. Email: gaspar@essec.edu. We thank participants in seminars at Essec Business School, Nova School of Business and Economics, Toulouse School of Economics, University of Paris-Dauphine and University of Porto, for their helpful comments. José-Miguel Gaspar kindly acknowledges the financial support of the ESSEC Private Equity Chair. 


\section{Introduction}

The private equity (PE) industry has enjoyed tremendous growth in the last three decades, and is now estimated to encompass more than 13,000 funds with around 3 trillion dollars of assets under management, ${ }^{1}$ of which roughly three quarters are dedicated to leveraged buyouts (LBOs). As the industry expanded during the last decade, one particular segment that has grown at even higher rate is secondary buyouts (SBOs), private equity transactions in which one PE fund sells its portfolio company to another PE fund. In our sample, SBOs constitute more than $20 \%$ of LBO activity and more than one-third of observed LBO exits in recent years.

While the rate of increase in secondary buyouts is puzzling, it is not a priori obvious what motivates PE funds to invest or exit this way. According to Jensen (1989) private equity funds have superior governance structures and incentive mechanisms, so it would follow that when they engage in secondary transactions, it is in the best interest of their investors. If, for example, PE funds specialize in different stages of restructuring, then funds specializing in the first stage of the process would sell to funds specializing in the second stage and each fund would create value for its own investors along the way. Alternatively, some GPs may have unique skills that others do not possess, so their funds would take over firms from other PE funds when their special skills are needed and generate additional returns. Thirdly, more reputable funds may be able succeed where other less experienced, less reputable ones do not, for example, they may have access to more deal financing at a cheaper rate, so investing in secondary deals would add value for these reputable funds.

A second view, in contrast, would suggest that these types of deals are likely to be chosen by self-serving GPs who place their own interest ahead of that of their investors. ${ }^{2}$ According to this view, private equity players pass unsuccessful portfolio companies from one fund to another aiming to collect management and transaction fees and to window-dress their fund's investment and performance in anticipation of a new round of fundraising. When a PE fund cannot exit an investment via trade sale, merger or IPO, it may enlist another PE fund as a "white knight" to acquire its portfolio company at a good price. On the buy side, when a PE fund has been unsuccessful to invest in traditional deals, it may resort to secondary buyout which is quicker to complete, fills the fund's investment record and reduces non-invested capital, even if the transaction is not in the best interest of the investors of the buyer fund. This view suggests that private equity contracts may not alleviate all conflicts of interests between GPs and LPs and may potentially create adverse incentives for GPs.

To investigate the motives of the sellers' and buyers' in secondary deals we put together a comprehensive dataset of 9,771 LBO transactions involving 8,758 target firms and 970 different PE acquirers. We extracted from S\&P's Capital IQ database all closed LBO transactions with targets

\footnotetext{
${ }^{1}$ Source: Preqin, Private Equity Spotlight August 2012.

${ }^{2}$ See e.g. The Economist, "Private-equity companies look to each other to solve their problems", February 232010.
} 
located in the U.S. and in 12 European countries from 1980 to 2010. We downloaded from Capital IQ data on corporate events for each target (bankruptcies, equity private placements, and mergers) and complemented this data with information on Initial Public Offerings (IPOs) from Thomson-Reuters' Securities Data Corporation (SDC) database. We constructed an "event history" of known corporate actions for each firm after the LBO, allowing us to identify the type and date of exit of the initial LBO investor. Our final sample contains 4,328 exits, of which 1,274 are secondary LBOs.

To identify which PE funds are more prone to conflict of interests and adverse incentives for window dressing, we consider typical contractual provisions in partnership agreements between GPs and LPs and how they impact the cross-section of PE funds. The typical fund has a lifetime of 10 years, after which it is dissolved with the remaining proceeds to be distributed among the LPs and the GPs. The closer is the fund to the end of its life, the more pressure the GPs face to sell their remaining portfolio investments. This is particularly true for funds that have not had successful exits in recent years and are desperate to window-dress their record. These incentives are likely to be stronger for funds with less reputational capital at stake.

The partnership agreements include strong incentives for the buy side as well. ${ }^{3}$ The GPs are expected to make investments only during the first five years of the fund's life, the called investment period. The management fee is set to incentivize them to do so. While the GPs are paid a percentage of the size of the fund or committed capital as management fee during the investment period, in later years the basis for the management fee is replaced with the invested capital. The later the fund invests, the less time the GPs have left to add value and realize returns, so this provision is meant to induce GPs starting their funds to make early investments. However, for PE funds close to the end of their fifth year with substantial "dry powder" this provision creates adverse incentives to enter whatever deal they can in order to lock in their management fee.

To ensure continued operations, PE sponsors aim to raise a new fund every three to five years. This overlapping fund structure is critical to stay in business. A GP's reputation affects his ability to raise the next fund (Kaplan and Schoar (2005), Chung, Sensoy, Stern, and Weisbach 2012), continued access to deal flow and favorable terms in deal financing. The pressure of being reevaluated every three to five years is part of the incentive mechanism to induce the GPs to make timely investments early in the life of their fund and to realize attractive returns later. Prospective LPs not only look at past performance and track record of previous funds but also at the rate of investment in the sponsor's young funds. If the most recent fund nearing the end of their investment period still sits on a lot of unspent capital, the GP will have a hard time to raise a new fund. This puts further pressure on PE funds late in their investment period to invest in order to use up their "dry powder" and to window-dress their record. There is a conflict of interest between the GP late in the investment period

\footnotetext{
${ }^{3}$ Metrick and Yasuda (2010) report relatively little variation across funds concerning these contract terms.
} 
of their funds with a lot of unspent capital and their LPs, since the potentially self-serving substandard investments at the end of the investment period would compromise future LP returns. These adverse incentives are stronger for funds with less reputational capital to lose.

While the PE contract induces value-maximizing behavior from an ex ante perspective at the start of the fund and reduces agency conflicts by ensuring that GPs do not hoard cash reserves or postpone exit forever, it may create adverse incentives later in the fund's life for GPs who fail to perform according to expectations. This suggests that there is a dynamic incentive provision story at play. The agency problem is likely to be more severe between GPs late in their investment period sitting on a lot of unspent capital and their LPs than between GPs late in their harvesting period and their LPs. For the seller fund, both the GPs and the LPs are in the same boat, interested in high multiples exits and the agency problem is not between these two but the GPs and their future LPs, who, based on the inflated returns of these secondary transactions, commit capital to the GP's next fund. For the buyer fund, the agency problem is between the GPs and the LPs of the current fund. When the GPs are desperate to invest, they are likely to invest at high prices, spend the management fee on money-losing investments and compromise LP returns at the exit stage. Thus, we predict that when a pressured seller meets a pressured buyer, the seller fund will have more bargaining power and can extract higher rents from the buyer fund.

To investigate whether secondary deals are indicative of opportunistic behavior by PE funds, we construct two composite indexes of characteristics that identify the type of funds most likely affected by adverse incentives and/or conflicts of interests. One of our indexes aims to capture a PE fund's pressure to invest (buy), while the other proxies for the GP's pressure to exit (sell). We predict that GPs are more likely to be under pressure to invest, if their fund is reaching the end of the investment period, if they have substantial non-invested capital, and/or if they have less reputational capital at stake. Similarly, we predict that GPs are more likely to be under pressure to sell if their funds are near the end of its life, if it had little recent exit activity, and/or if it has not built up a lot of reputational capital. We conjecture that buyers under pressure to invest are likely to pay higher prices, whereas sellers under pressure to exit are likely to accept lower prices for their portfolio companies. Finding no evidence for opportunistic behavior would provide support for Jensen's view that the GPs and the LPs interests are well aligned and secondary transactions are driven by shareholder value maximizing strategies of the GPs, or if there is an agency problem, its nature is different.

Our empirical analysis documents that secondary purchases are more likely to involve buyers under pressure. The regression coefficients indicate that a one unit change in our index of buying pressure increases the likelihood of an SBO from $16.5 \%$ to $19.5 \%$, or about $18 \%$ of the unconditional probability. Simultaneously, we find that buying pressure has an impact on SBO valuations. PE funds under pressure to invest pay relatively more for secondary buyouts, with a one unit shock in the index increasing the excess purchase multiple (relative to comparable M\&A transactions) by about $10 \%$. 
Regarding sellers, we find that an exit through a secondary deal is more likely if the seller is under pressure: an increase of one unit shock in our index increases the likelihood of an SBO exit from $29.4 \%$ to $33 \%$, or a $12 \%$ increase. We also find evidence that sellers under pressure sell at lower prices, but the evidence in this regard is somewhat weaker. Results for transactions in which both buyers and sellers are under pressure indicate that sellers have most of the bargaining power. The presence of buyers under pressure to invest pushes the prices up but the reverse effect is not supported by the data.

Our finding provides support the view that the boom in secondary activities is driven by PE funds under pressure to invest at any price. The following quote from Private Equity International, June 10, 2010 well describes this view: "Deal intermediaries in London now use a not very flattering label for fund managers facing pressure to invest their capital promptly: ‘desperate housewives'. [...] If you are a banker shopping a company, you track down those managers with unspent capital in their aging funds, struggling to extend their investment period and, crucially, who can't raise new money until the tail is gone. They are basically dying to do a deal, at almost any price. The result is a deal market heavily skewed towards them, where businesses get sold at big multiples, [...] which helps explain the secondary buyout spree of late. Buyout funds in exit mode invariably sell to the highest bidder, so given this flurry of activity with financial buyers outbidding strategic ones, it is hard to resist the conclusion that desperate housewives are indeed at large."

Our buy pressure index has a strong negative impact on the leverage of the deal. We find that buyer funds under pressure use less leverage in their LBO transactions than other buyers and even less when they engage in secondary buyouts. This evidence goes against received wisdom that secondary buyouts employ more leverage than primary deals. Our finding that funds under buy pressure use more equity in their investment when they do secondary deals further supports the view that secondary transactions involving pressured buyers are driven more by the buyers' desire to reduce their uninvested capital than by maximizing LP returns. As a further robustness check, we look at whether secondary deals are more likely to occur between specialized buyer and seller funds aiming to create value for each fund's own investors along the way but we do not find evidence that fund specialization have explanatory power for the choice secondary deals.

A considerable amount of research has been devoted to private equity and LBO activity on a wide variety of questions, including productivity, growth, employment, financial distress and the performance of $\mathrm{PE}$ as an asset class. ${ }^{4}$ Our paper is most closely related to studies on the efficiency of PE investments. Like Axelson et al. (2009) and Axelson et al. (2012), we document PE sponsors

\footnotetext{
${ }^{4}$ See among many others, Kaplan (1989a, 1989b), Smith (1990), Stromberg (2008), Acharya, Hahn and Kehoe (2009), Phalippou and Gottschalg (2009), Axelson, Jenkinson, Stromberg and Weisbach (2012), Demiroglu and James (2010), Officer, Ozbas, and Sensoy (2010), Boucly, Sraer and Thesmar (2011), Guo, Hotchkiss and Song (2011), and Franzoni, Nowak, and Phalippou (2012).
} 
incentives to overinvest. While Axelson et al (2012) documents overinvestment tendencies in a time series context for the PE industry as a whole, we report evidence related to overinvestment for a cross-section of private equity funds with specific fund characteristics. Our work is also related to a small but growing literature on adverse effects of the limited investment horizon of PE funds, notably Kandel, Leshchinskii and Yuklea (2011) and Barrot (2012).

Our paper also contributes to a small but growing literature on secondary buyouts. Investigating the motives for secondary buyouts, Wang (2012), Jenkinson and Sousa (2012), and Achleitner et al. (2012) find that SBOs are mainly driven by favorable debt market conditions and the state of the IPO market. Bonini (2010), Jenkinson and Sousa (2011), and Wang (2012) analyze operating performance of SBOs and report evidence of underperformance of these deals compared to primary deals. Looking at internal rates of return from a proprietary dataset, Achleitner and Figge (2012) and Achleitner et al. (2012) find no difference in performance between primary and secondary deals. Our paper complements these findings by focusing on the GP's incentives in partnership agreements that drive the choice of secondary deals and by documenting that PE funds under pressure to invest and/or exit are more likely to buy or sell in secondary transactions. In a contemporaneous and independent paper to ours, Degeorge, Martin and Phalippou (2012) find that funds underperform when investing in SBOs at the end of their investment period relative to their other investments and relative to their SBOs undertaken earlier. While our investigation of the relationship between fund incentives and SBO activity shows that both buy pressure and sell pressure explain the heightened frequency of SBOs and pricing pressure on both ends, their underperformance result complements our finding that PE funds pay more when they face buy pressure.

The remainder of the paper is organized as follows. We develop our hypothesis in Section 1. Section 2 describes the data and the variables we use. Section 3 analyzes the impact of the "pressure to invest" on the likelihood and valuation of secondary LBOs. Section 4 presents results related to the "pressure to exit" on the likelihood of an exit via a secondary and its impact on valuation. Section 5 shows which effect dominates. A brief conclusion follows.

\section{Hypothesis Development}

It is useful to begin with a brief description of how PE funds are organized. The management company, or the general partner (GP), sets up the fund and takes all investment and divestment decisions. Investors, or limited partners (LPs), commit to transfer capital to the fund whenever the GP finds an investment opportunity and sends out a capital call. The LPs play no active role in the fund's management, and have no specific information upfront of what particular investments the GP will make after the fund is closed (i.e., PE funds are "blind-pool" vehicles). The limited partnership has a 
lifetime of 10 years (extendable by a maximum of one or two more years) that is divided into two distinct periods. The investment period normally lasts up to 5 or 6 years after the fund's inception; this is the period during which the GPs select the companies to invest, perform due diligence and invest after calling on the LPs' commitments. The divestment period or management period refers to the remaining years of the fund's lifetime, during which new investments are discouraged and the GP aims to exit from investments made at a profit. $^{5}$

GPs are compensated in two main ways: a fixed management fee, typically $1.5 \%$ to $2 \%$ of assets under management; and a variable component known as carried interest (or carry), corresponding (in the overwhelming majority of cases) to $20 \%$ of the fund's profits (often a prespecified hurdle rate must be reached before the GP can receive carry). This convex claim held by the GP is what aligns the incentives of both parties. Note that the incentives are critically important since the LPs are locked in with the fund for ten years once the fund is closed and have no say in the investment and exit decisions. When the fund makes a successful exit, the proceeds have to be distributed to the LPs and the GPs. Apart from eventual distributions corresponding to exits, the LP's stake is illiquid and selling this stake is either not possible or extremely costly, and is usually subject to GP approval. Therefore, once the fund is closed, the only 'stick' that the LPs possess is the threat not to invest in subsequent funds by the same GP. This is a strong threat, since the GP will be out of a job at the end of the current fund's lifetime, if future fundraising is unsuccessful.

How does this organization structure impact GP's investment behavior and what are the corresponding hypotheses that we can formulate? First, we postulate that the GP-LP relationship can be viewed as a principal-agent problem in which an uninformed principal (representative of the LPs) hires a (potentially skilled) agent (the GP) to trade on his behalf. ${ }^{6}$ In this asymmetric information setting, the investor learns about the ability of the GP by observing deal activity and performance. In an important paper, Dow and Gorton (1997) have shown that the agent would try to influence the principal's perception of his ability by "churning" its portfolio, i.e. engaging in trades even when doing so might not be optimal. The intuition for this result is as follows. Suppose the agent (the GP) diligently exerts effort only to find that there are no suitable investment opportunities to cover the principal's (the LP) cost of capital. The LPs cannot distinguish this situation from an alternative scenario in which the GP simply consumes the fixed fee and shirks; in the terminology of Dow and Gorton the principal cannot distinguish between "actively" searching for investment opportunities and "simply" doing nothing. Furthermore, inaction is never rewarded, since doing so would attract lazy or incompetent managers. As a result, in equilibrium there is excessive deal activity by the GP, because the latter has every incentive to engage in deals in order to show activity to the principal. This

\footnotetext{
${ }^{5}$ So called follow-on investments, usually acquisitions made by companies already in the fund's portfolio, are sometimes allowed, but these are typically limited to at most $10 \%$ to $15 \%$ of the fund's size and must be authorized by the LPs.

${ }^{6}$ See e.g. Berk and Green (2004).
} 
problem, although applicable to all managers, would be more severe for managers that need to build their reputation and less so for established ones.

Second, the compensation structure of private equity is also likely to induce the GP to engage in excessive deal making, for two reasons. First, as Metrick and Yasuda (2010) simulate data on observed PE contract features, they go on to show that the fixed compensation component represents a large portion (roughly $60 \%$ ) of the net present value of flows accruing to the GP. Second, their data indicates that for about $84 \%$ of buyout funds, the fixed fee is calculated as a percentage of capital committed during the investment period but as a percentage of capital actually invested in the management or divestment period. Therefore, GPs considering new investment close to the end of the investment period face a tradeoff. Suppose that the target in question is somewhat overvalued. This implies, on the one hand, that the fund's internal rate of return (and hence its carry) would be correspondingly lower if the GP makes the investment. On the other hand, not doing the deal would mean that the management fees will sharply decrease (as their basis will shift from committed capital to invested capital) and the fund's operation may no longer be sustainable. The tradeoff between the two will determine whether the GP will make or pass up this investment. Given Metrick and Yasuda's findings, the temptation to overinvest will probably be strong. ${ }^{7}$

The arguments above suggest that under some circumstances PE fund managers will face pressure to overinvest: to engage in more and larger deals. Among all available deal sources, secondary buyouts are particularly attractive for a fund that wishes to conclude a deal quickly, for several reasons. First, a fund buying into a secondary deal saves on search costs, because the target has already been pre-screened by the primary PE investor. Second, anecdotal evidence suggests that because of the seller fund's incentives to exit promptly, SBOs are faster to complete relative to divisional deals (in which the decision process by the corporate parent might be more convoluted or involve more intermediaries), delistings of public firms (in which the buyer has to contend with delisting regulations and possible hold-out by minority shareholders), and sales of family firms (in which the emotional attachment of the founder or conflicts among family members can delay the sale process). In particular, if the seller fund is close to the end of its lifetime, or its GP is planning to raise a new fund and wants to show off some recent profitable exits, the seller has a strong incentive to complete the deal fast and the transaction cost is likely to be lower. Third, SBOs are probably easier to finance since a substantial amount of information production has occurred at the time of the primary deal (in the form of debt documentation, due diligence, financial reporting systems put in place by the primary owner) that is a sunk cost at the time of the secondary deal. Furthermore, lenders

\footnotetext{
${ }^{7}$ Chung, Sensoy, Stern and Weisbach (2010) suggest that the prospect of raising another fund constitute an important source of performance-sensitive compensation that might restore incentives. However the argument still holds that the change in fee basis induces the temptation to increase the invested capital during the management period.
} 
are likely to be familiar with the target and the same banks may be willing to continue to fund it after the secondary transaction.

Hence, we predict that, from a buyer's perspective, fund managers are under more pressure to engage in secondary deals: (i) if they have more capital available to spend ("dry powder" in the industry's jargon), since letting the capital commitment expire unexercised will reflect negatively on the LP's perception of the GP's ability; (ii) if their fund is reaching the end of the investment period, because they have the opportunity to lock in management fees that would be lost if committed capital remains unspent; (iii) if they do not belong to the top group of high-reputation funds, and hence have less access to quality deal flow than players with established top reputation (i.e. face higher search costs for new deals. Simultaneously, we predict that a buyer under such elevated pressure to buy in a secondary deal has a weak bargaining position, leading to higher prices for these types of deals.

From a seller's perspective, the pressure to exit is likely to be higher for a private equity fund: (i) if the seller hasn't exited a deal for some time, as this absence of activity and related distributions would negatively affect LP's beliefs about GP skills; (ii) if the fund that owns the target firm is reaching the end of its lifetime; (iii) if the seller is not a high-reputation GP, and hence a missed or delayed exit is more harmful to future fundraising prospects. For sellers, a secondary sale is an attractive transaction for several reasons. First, initial public offerings (IPOs) are time-consuming, costly, and cannot always be used as an exit route due to cold IPO periods. Second, trade buyers might take more time to react to deal opportunities, compared to financial buyers, and are more likely to be constrained by antitrust concerns or shallow pockets. Again, in terms of valuation sellers under pressure to exit are likely to accept lower prices for their portfolio companies. However, conditional on an acceptable offer, sellers under pressure are more likely to do a secondary deal now than to hold out for another more attractive exit option later.

\section{Data and Empirical Testing Issues}

This section describes in general terms how we generated our sample and variables. Appendix A provides the full details of the sample construction procedure, and Appendix B presents the full list of variables and their definitions.

\subsection{Sample Construction}

We extracted from S\&P's Capital IQ database all closed LBO transactions with targets located in the U.S. and in 12 European countries (Belgium, Denmark, Finland, France, Germany, Italy, Luxembourg, Netherlands, Spain, Sweden, Switzerland, and United Kingdom) for the period 
ranging from January 1st, 1980 to December 31st, 2010. As a first set of filters we excluded targets in financial industries, acquisitions of minority stakes or of remaining interest, deals involving targets with reported negative sales or negative enterprise value, and misclassified non-PE related transactions such as corporate acquisitions, purchases of stakes by hedge funds, and venture capital deals. On this initial sample of 23,032 deals we implement Strömberg's (2008) methodology to obtain an imputed Enterprise Value for transactions without deal value information (roughly $60 \%$ of the sample). This involves running a Heckman regression model with the likelihood of a deal having its value disclosed in the first stage, and the determinants of target Enterprise Value in the second stage (see Table A-1 in the Appendix for results and details). This imputed value is used to compute market shares and activity measures of PE fund families required in the analysis.

We then apply a second set of filters excluding: deals without Capital IQ identifiers of buyers and sellers; acquisitions by management teams (management buy-outs) with no evidence of involvement by a PE sponsor; deals in which the target firm is bankrupt or in financial distress; and transactions with a deal value lower than one million dollars. ${ }^{8}$ When an acquisition involves multiple stages or transactions, we keep the one in which the buyer acquired most of its stake (typically the first transaction). We also require that we can reasonably trace the purchase to a given fund within a PE fund family under mild assumptions (see below). The final sample contains 9,771 LBO deals involving 8,758 target firms and 970 different PE acquirers.

To obtain the exit of each LBO transaction, we download from Capital IQ data on corporate events related to each target firm (bankruptcies, equity private placements, and mergers) using each firm's unique identifier. We complement this data with information on Initial Public Offerings (IPOs) from ThomsonReuters' Securities Data Corporation (SDC) database. We then construct an "event history" of known corporate actions for each firm after the LBO, allowing us to identify the type and date of exit of the initial LBO investor. We say that an exit takes place if there is evidence of a change in control (e.g., sale of a majority stake) even if the original buyer funds remain minority shareholders. The final sample contains 4,328 exits, of which 1,274 are secondary LBOs.

\subsection{Buyer-related variables}

We extract from Capital IQ buyer and seller information that we use to create a unique PE fund family identifier to group fund-level information (again see the Appendix A for details). We identify the "leading buyer" in a multi-buyer transaction as the PE fund family with the highest reputation among the deal's buyers, measured as the dollar market share across all LBO deals made

\footnotetext{
${ }^{8}$ All monetary amounts in this paper are in real December 2010 dollars, values in European currency having been converted to U.S. dollars at historical exchange rates.
} 
up to that year. ${ }^{9}$ For single-buyer transactions, the "leading buyer" (henceforth, the buyer) is the PE fund family of the acquiring fund. We then match each LBO deal with information on the buyer's existing funds. We check if the LBO's acquisition date is within the investment period range (e.g., years 1 through 6) of at least one of the funds in the PE fund family. If the condition is not fulfilled, we discard the LBO transaction because that is a sign that fund-level information in Capital IQ about the family is incomplete. If the condition is fulfilled, we assume that the deal is performed by the fund family's youngest fund still investing at the time of the deal. We therefore create the variables: Stage, the time in the fund's lifecycle at which the deal is made (that is, the number of years elapsed since the raising of the buyer's fund); and Late Buyer, an indicator variable equal to 1 if the buyer's fund is at the end of its investment period (that is, 4 to 6 years after inception) at the time of the deal, and zero otherwise.

To proxy for the pressure to buy, we create several other variables. First, for each PE fund family and year, we calculate: (i) the aggregate amount that was raised in the past 3 years and the corresponding median that was raised across fund families in that year; (2) the aggregate dollar value of all investments made during the past three years, and its corresponding median. Using these two quantities, we define Dry Powder, a dummy variable equal to 1 if the buyer's PE fund family is above median in terms of fund raising and below median in terms of deal activity. Second, we define Lack of Reputation, an indicator variable equal to 1 if the buyer is not among the PEI Media Top 50 PE firms, and zero otherwise. Third, the index variable Buyer Pressure is created as the sum of dummy variables Dry Powder, Late Buyer, and Lack of Reputation.

Finally, to control for fund family characteristics, we create two other control variables: Affiliated, a dummy variable equal to 1 if the fund family is affiliated to a financial institution or government agency, and zero otherwise; and Novice, an indicator variable equal to 1 if the buyer is from a PE fund family with 3 funds or less under management at the time of the LBO deal, and zero otherwise.

\subsection{Seller-related variables}

In line with the buyer-related variables, we define the seller-related variables with respect to the time of the LBO exit. The "leading seller" at the exit is the PE fund family initially selected as leading buyer, and for consistency we assume that the selling fund (within the family) is the same

\footnotetext{
${ }^{9}$ We also compute market shares of PE fund families using three other backward-looking horizons, 3, 5, and 10 years. In the overwhelming majority of cases the ranking of fund families, and thus the leading buyer, is the same. In very small number of cases in which the different horizons produce different results, we take the buyer with the highest average among the all horizons.
} 
fund assumed as buyer at the initial transaction. ${ }^{10}$ Armed with these definitions, we compute several variables for the pressure to sell: Late Exit is an indicator variable equal to 1 if three years or more elapsed since the PE fund family last exited an LBO deal; Late Seller is a dummy variable that takes the value of 1 if the exit takes place in year 9 or 10 of the life of the selling fund, and zero otherwise; Lack of Reputation, an indicator variable equal to 1 if the buyer is not among the PEI Media Top 50 PE firms, and zero otherwise. We then define our index of Sell Pressure as the sum of the variables Late Exit, Late Seller, and Lack of Reputation. For completeness, we also compute Novice at Exit, an indicator variable equal to 1 if at the time of exit from the LBO deal the buyer is a PE fund family with 3 funds or less under management and zero otherwise.

\subsection{Other variables}

The set of controls in our regression specifications includes several variables. Imputed TEV is the target's enterprise value, that is, the sum of equity market value (valued at the offer price) and the target's pre-deal net debt (financial debt minus cash and marketable securities). Enterprise value, like all monetary amounts in this paper, is measured in real December 2010 U.S. dollars after conversion at historical exchange rates (exchange rates and inflation rates are obtained from the FRED Economic data of the Federal Reserve Bank of St. Louis). Management Participation, U.S. dummy, and Syndicated are dummy variables that indicate, respectively, that management is a shareholder of the acquiring group, the target is a U.S. firm, and there is more than one buyer. As proxies for capital market conditions, we include HY Spread, the difference between interest rates on leveraged loans and on AAA-rated bonds, and Cold IPO Market, an indicator variable equal to 1 if the geography-, industry-adjusted IPO dollar volumes are below their time series average.

The tests concerning entry valuations use as dependent variables the Excess Sales Multiple and the Excess Ebitda Multiple, both constructed as follows. We first compute for each LBO deal the Sales Multiple (Ebitda Multiple) as the ratio between Enterprise Value (TEV) and latest available yearly sales (Ebitda) for the target firm at the time of the LBO. Multiples are constructed only when the deal value is non-missing, that is, Imputed TEVs are not used in this calculation. To obtain the benchmarked variables, we subtract from each multiple the median sales (Ebitda) multiple by geography (U.S. versus Europe), industry (Fama-French 12-industry classification), and public status (public or private), of all merger transactions from ThomsonReuters' SDC over the previous two years relative to the date of the LBO.

\footnotetext{
${ }^{10}$ In a few cases, LBOs are marked as secondary deals in Capital IQ but no information related to the primary deal exists. In this case we replicate the process described above for the buyer, that is, we compute market shares among sellers in a deal to select the leading seller, and require that the sale takes place during the lifecycle (i.e. years 1 through 10) of at least one fund in the selling family to compute seller-related variables. The selling fund is then defined as the oldest active fund (i.e. less than 11 years old) in the selling fund family.
} 
For tests involving exit, we construct similar variables but computed as of the time of exit (Exit HY Spread, Exit Cold IPO Market, and Exit Excess Sales (Ebitda) Multiple). One additional variable specific to exit regressions is Add-ons, a dummy variable equal to one if there were significant acquisitions during the time that the buyer held the target firm in its portfolio.

\subsection{Summary Statistics}

Table 1 presents the main characteristics of our LBO sample. Panel A shows that the average (imputed) Enterprise Value is 281 million (M) USD, while the median is 87 M. Management is part of the acquiring group $44 \%$ of the time, and slightly more than half of our deals refer to U.S. targets and have more than one buyer. Our proxy for dry powder indicates that buyers have significant capital available $23 \%$ of the time. About $21 \%$ of LBO deals are made in the last years of the buyer's investment period, and 76\% are made by fund families outside the PEI Top 50. The value of our buying pressure index is 1.2(1) for the average (median) buyer fund. For completeness, Panel A also shows the proportion of other LBO types present in the sample, of which the largest fraction is from private sellers (53.6\%) and divestitures by corporations (19.4\%).

Panel B of Table 1 presents summary statistics for our valuation variables (recall that valuation measures are only available if the deal value is known and the accounting item entering the multiple is also available). The average Sales Multiple (Ebitda Multiple) for LBOs in our sample is 1.39 (9.39), while their Excess equivalent, net of median transaction multiples, is 0.28 (-1.3).

Finally, Panels C and D of Table 1 present statistics for exits. 29\% of the LBOs in our sample are exited through a secondary deal, the second most frequent form of exit after trade sales (48\%). About $11 \%$ of exited deals involved significant acquisitions. Among the sellers $10.4 \%$ have last exited a deal three or more years ago, $12.6 \%$ sell at the end of the fund's lifetime, and $68.8 \%$ of exits involve firms without reputation. Our index for the pressure to sell has a value of 92 (1) for the average (median) fund. For valuation, the average Sales Multiple at exit is 1.86 and the average Ebitda Multiple is 10.8 , somewhat higher than the corresponding entry valuations. The same pattern holds for the excess sales multiple (excess Ebitda multiple) which reach 0.76 (0.82).

\section{Secondary Buyouts and the Pressure to Invest}

\subsection{Secondary Buyouts: Univariate Comparisons}

To better understand the systematic differences between secondary LBOs and other buyouts, Table 2 shows univariate comparisons of means and medians of our variables between these two types 
of deals. Panel A shows that, relative to non-secondary LBOs, secondaries are larger both in the mean and in the median, are more often syndicated, and management participates more often as equity holder (all differences statistically significant at 1\%). Secondary buyouts are more likely to occur when credit spreads are relatively lower, and more often when IPO markets are cold (all differences again statistically significant at $1 \%$ ).

For our main variables of interest Panel A of Table 2 presents a preview of our main results. We report that secondary LBOs more often involve (1) buyers with Dry Powder $(26.2 \%$ of the time versus $22.6 \%$ for non-secondaries, statistically significant at $1 \%$ ), (2) buyers late in their investment cycle $(23.9 \%$ versus $20.8 \%$, statistically significant at $1 \%)$, and (3) buyers without high reputation ( $77.9 \%$ versus $76 \%$, but the difference is not statistically significant). The Buy Pressure index is therefore higher for secondaries (1.28 versus 1.19 , statistically significant at $1 \%)$. The table also shows that affiliated buyers do secondaries relatively more often, and novice funds less often than other deals. This shows the importance of controlling for these fund characteristics in our analysis.

Panel B reports the differences in valuation between the two types of deals. The table shows that secondary deals are more expensive than other LBOs across all valuation measures employed. For example, the average secondary transaction in our sample was priced at a sales (Ebitda) multiple of $1.61(10.16)$, about $20 \%(13 \%)$ higher than the multiple for other types of deals. The results for the benchmarked excess multiples are similar (all differences statistically significant at 5\% or less).

\subsection{Secondary Buyouts: Multivariate Analysis}

We run a multivariate Logit regression to test our hypothesis that PE fund characteristics proxy for investment incentives and predict secondary transactions:

$$
y_{1, i}=\alpha_{1}+\beta_{1} \times \text { Buy Pressure }_{i}+\gamma_{1} X_{i}+\varepsilon_{i} \quad y_{1, i}=\left\{\begin{array}{l}
0 \text { if } y_{1, i}^{*} \leq 0 \\
1 \text { if } y_{1, i}^{*}>0
\end{array}\right.
$$

The dependent variable, $y_{i}$, is an indicator that takes value 1 if deal $i$ is a secondary buyout and 0 if the LBO is a primary deal. $\mathbf{X}$ represents the matrix of control variables defined in section 2.4. All regression specifications include industry-and year-dummies, and we cluster standard errors by deal year.

Column 1 of Table 3 presents the results from estimating the logistic model for our basic specification. The coefficient of Buy Pressure is positive and highly significant (t-statistic 4.82). This suggests that buyers that are more likely to be under pressure to invest when deciding whether to engage in secondary deals do proportionally more. The marginal effect of Buy Pressure (not shown in the table) is 0.030, implying that an increase of one standard deviation in Buy Pressure represents an 
increase in the probability of doing a secondary exit of about $0.030 \times 0.724=2.2 \%{ }^{11}$ This is a 13.3 percent increase relative to the unconditional mean of the likelihood of a secondary (equal to $16.5 \%$ from Table 1).

Columns 2 through 4 of Table 3 present results for the individual components of our Buy Pressure index as the main independent variables. All coefficients show a positive loading, with statistically significant t-statistics ranging from 2.2 (Dry Powder) to 5.1 (Lack of Reputation). To gauge robustness, we implement two other specifications with additional buyer characteristics Affiliated and Novice as well as market condition variables HY Spread and Cold IPO Market included among out set of controls. Evidence presented in Column 5 of Table 3 show that affiliated funds participate more often in secondary buyouts (t-stat. 2.17), and this type of deal is less likely in times of tight credit conditions (t-stat. -1.67). Column 6 displays results from the subsample with observations on deal value (the size variable TEV refers not to imputed TEV but to actual TEV). Although the number of observations drops to 4,237 and $\mathrm{R}^{2}$ decreases slightly, our Buy Pressure index is still statistically significant with a similar point estimate as in the larger sample (coefficient 0.225 , t-stat. 3.82).

From the coefficients on our other variables we report that targets of secondary LBOs are larger than primary deals (with very large t-statistics between 10 and 20) and have management equity participation more often (t-statistics ranging between 4 and 6). Secondary transactions seem to be somewhat less prevalent in the U.S. compared to Europe (t-statistics around -2.5). Finally, and in contrast with the univariate evidence, syndication is negatively correlated with the likelihood of a secondary, even though this result is statistically significant only in some specifications.

\subsection{Likelihood of secondary deals and buyer specialization}

Our findings so far suggest that pressure plays a role in funds' investment decisions, but at least two sets of alternative stories can explain why some funds might have a preference to engage in secondary deals.

The first alternative story relates to fund specialization. Industry practitioners argue that PE funds have different skills that are adapted to each type of target. Compared to primary targets, secondary targets have different characteristics: they are larger, more mature, and have survived the first leveraging up. The value creation levers required to make each type of deal succeed might also be different: for example, organic strategies based on professionalization of business practices might be more likely in smaller primary targets, while M\&A-driven internationalization strategies could be more prevalent among larger secondary targets (e.g. Acharya et al., 2013). Funds would therefore

\footnotetext{
${ }^{11}$ All marginal effects in this paper are evaluated using the sample average of the individual marginal effects.
} 
self-select into each type of target according to their specific skills, and this matching would partially explain our results.

To test for this possibility, we conduct robustness checks adding two proxies for buyer specialization in our model. The first proxy is Industry Specialization, an indicator variable equal to 1 if a significant percentage of the buyer's past deals (33\%) occurred in the same industry as the target. The second proxy is a set of three indicator variables related to Size Specialization, that take the value 1 if the buyer's past deals are particularly focused (more than two thirds) in a particular LBO size category. We define a deal as being in the small (medium) [large] size category if the deal has an imputed enterprise value lower than 50 million (between 50 and 250 million) [more than 250 million] real 2010 U.S. dollars. These cutoffs roughly correspond to standard practitioner categorizations used by PE trade associations.

Table 3B presents results for the estimation of the Logit model of the previous section, with the addition of the specialization variables in columns 1 through 4 . The specification includes the same set of control variables, as well as industry and year dummies. The results indicate that fund specialization does not seem to play a role in the results, contradicting the specialization hypothesis. All of the coefficients of the specialization variables are statistically insignificant, and their signs are the opposite of what one would expect. Column 1 shows that specialist funds in an industry are not more likely to make a secondary deal on that industry, and that funds specialized in large deals are less, rather than more, likely to purchase a secondary target. Notably, the coefficient of the Buy Pressure variable is positive and statistically significant throughout.

The second alternative channel refers to industry- or market-specific conditions that might affect the likelihood of a secondary deal being chosen. Although we control for industry and time effects, some within-industry time varying factors could potentially play a role in our results. We focus on three possibilities. The first possibility is that anti-trust concerns might affect the frequency of secondary deals. Secondary LBOs are relatively larger firms, which might face anti-trust hurdles if bought by a trade buyer, while simultaneously not being large enough to be sold through an IPO. Hence in the presence of substantial industry concentration, the only exit route for a seller would be to exit through a secondary LBO. We therefore use as a control Industry Concentration, the geographyand year-adjusted Herfindahl concentration index in the target's industry. The second possibility is that changes in industry capital asset liquidity might explain the likelihood of secondary deals, by making the pool of available trade buyers change over time. We therefore use as a control the Asset Liquidity measure proposed by Schlingemann, Stulz and Walkling (2002), defined as the target industry's ratio of the value of corporate transactions (excluding LBOs) to the value of the total assets of public firms in that industry. Finally, we investigate the possibility that Buy Pressure is picking up a possible pent-up supply of LBO deals. Under this view, past LBO activity is correlated with current Buy Pressure (because funds flow to the PE industry in periods of high activity, and some of these 
result in dry powder when LBO activity slows down) and current secondary activity (because there are more targets coming to market 3 to 5 years after the boom). We therefore insert as a control Past LBO Activity, the log of the moving 5-year average of LBO volumes, measured in billions of real 2010 U.S. dollars.

Columns 5 and 6 of Table 3B present results of the tests of these alternative stories. While the coefficients of Industry Concentration and Asset Liquidity are undistinguishable from zero, the coefficient of Past LBO activity is positive and statistically significant (t-statistic 2.28). This indicates that secondary activity increases after periods of significant overall LBO activity. However, the variable Buy Pressure shows coefficients of unchanged statistical and economic magnitude. We conclude that these factors are not responsible for our findings.

\subsection{Valuation of Secondary Buyouts}

Our empirical analysis provides support that our index for PE fund's pressure to invest predicts the likelihood of secondary deals. Next we will investigate at what prices funds under pressure close their deals. To gauge valuation effects, we run the following least-squares regression in the sample of deals with valuation information:

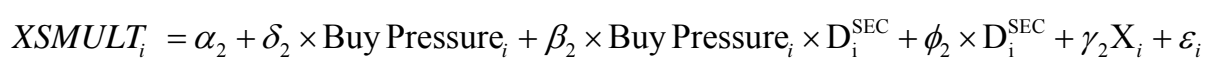

where XSMULT, the dependent variable, is one of our two measures of deal valuation (Excess Sales Multiple or Excess Ebitda Multiple) and $D^{S E C}$ is an indicator variable that takes the value 1 if the deal is a secondary transaction and 0 otherwise. We focus of attention on $\beta_{2}$, the coefficient on the interaction term Buy Pressure $\times D^{S E C}$ which measures the impact of our buy pressure index for secondary deals. As before, $\mathbf{X}$ represents the matrix of control variables, but with one exception: we replace TEV (which is part of our Sales Multiple definition) with an instrument for deal size, represented by Buyer Size, the log value of all deals made by the buyer in the last 5 years. All specifications include industry- and year-dummies and year-clustered standard errors.

Column 1 of Panel A, Table 4 presents our main results. For brevity we focus the discussion on the Excess Sales Multiple results of Panel A (results of Panel B using Excess Ebitda Multiple are similar in magnitude and slightly stronger in terms of statistical significance). The coefficient $\delta_{2}$ that measures the impact of our Buy Pressure index on deal value is negative and statistically significant the $10 \%$ level (coefficient -0.188 , t-stat. 1.77), albeit not in all specifications. This implies that buyers under pressure to invest would tend to buy less expensive targets in general. In contrast, our coefficient of interest $\beta_{2}$ is positive and statistically significant (coeff._0.218, t-stat. 2.57), indicating 
that for secondary deals higher pressure to invest is associated with higher multiples paid. Taking the difference between these coefficients and multiplying by a one-standard deviation shock of 0.72 in Buy Pressure, we obtain a change of 0.021 in Excess Sales Multiple, equivalent to an increase of 7.6\% with respect to the sample average of this valuation measure ( 0.283 from Table 1$)$.

Columns 2 through 4 show regression results for the individual components of our Buy Pressure index. Late buyers (t-stat. -1.91), and particularly buyers that lack reputation (t-stat. -6.13) tend to engage in cheaper acquisitions; the interaction terms Dry Powder $\times D^{S E C}$ and Late Buyer $\times$ $D^{S E C}$ are positive and statistically significant at the $10 \%$ level, while the interaction Lack of Reputation $\times D^{S E C}$ has a negative sign but is not distinguishable from zero. Purchase prices are positively associated with our proxy for deal size and negatively related to management equity participation, although statistical significance depends on the precise specification. Results using the extended set of controls (column 5) show that affiliated buyers also tend to pay lower prices.

For robustness check we also estimate our regression exclusively within the set of secondary LBOs. As column 6 shows the coefficient of the Buy Pressure variable is positive and significant (coefficient: 0.146, t-stat. 2.47). Comparative statics in this subsample (which has an average Excess Sales Multiple of 0.61) indicates that the impact of a standard deviation increase in Buy Pressure would increase prices by 0.11 , or about $17 \%$ of the average excess multiple.

\section{Exits via Secondary Deals and the Pressure to Sell}

\subsection{Determinants of Secondary Exit Route}

We run a multivariate logistic model to test our hypothesis that PE fund characteristics proxy for investment incentives and predict secondary exits:

$$
y_{3, i}=\alpha_{3}+\beta_{3} \times \text { Sell Pressure }_{i}+\gamma_{3} X_{i}+\varepsilon_{i} \quad y_{3, i}=\left\{\begin{array}{l}
0 \text { if } y_{3, i}^{*} \leq 0 \\
1 \text { if } y_{3, i}^{*}>0
\end{array}\right.
$$

The dependent variable, $y_{3}$ is an indicator variable that takes value 1 if deal $i$ is exited via a secondary buyout and 0 other types of exits. We modify the control variable matrix $\mathbf{X}$ by adding the following variables as controls: Stage, the time of the fund's lifecycle at which the target was originally bought; Add-On, an indicator of significant build-ups during the tenure of the seller; and dummy variables identifying the original deal's source, that is, whether it was itself a secondary deal, or a divisional, public-to-private; of financial seller LBO (the missing category is that of a private-to-private deal). In addition, some of our variables, like Novice, HY Spread, and Cold IPO Market, are now calculated as of the date of exit. 
The results are presented in Table 5. Column 1 shows that pressured sellers are more likely to exit through a secondary buyout (coefficient: 0.183 , t-stat. 3.20). The marginal effect (not shown) of the Sell Pressure variable is 0.036. Given that the standard deviation of Sell Pressure in the exit sample is 0.691, a one standard-deviation shock of Sell Pressure would increase the likelihood of an exit through a secondary LBO by $2.5 \%$, or about $8.5 \%$ of the average sample frequency of secondary exits. This result is robust to the inclusion of variables related to market conditions (column 5) and remains the same when we run the regression on the subsample of LBOs with valuation information. The individual components of the pressure index are also positive and statistically significant, with tstatistics ranging from 1.89 (Lack of Reputation) to 2.24 (Late Seller).

Table 5 also shows that the deal's initial source is a strong determinant of exit type, with secondary deals highly likely to follow secondary deals (t-stats in the range of 3 , for all but one specification) while targets originally divested by corporate sellers are less likely to be resold to a PE fund. In addition, market conditions matter: the variable HY Spread is negative and statistically significant (t-stat. -4.97), indicating that at times of high credit spreads this type of exit is more difficult.

\subsection{Valuation of Secondary Exits}

The empirical analysis provided support that our index for pressure to exit predicts higher likelihood for secondary deals by PE funds. Next we investigate the prices at which funds under pressure close their deals. To test our hypothesis regarding exit valuations, we run the following regression model:

$$
\operatorname{XSMULT}_{i}^{\text {EXIT }}=\alpha_{4}+\delta_{4} \times \text { Sell Pressure }_{i}+\beta_{4} \times \text { Sell }_{\text {Pressure }_{i}} \times \mathrm{D}_{\mathrm{i}}^{\text {SECEXIT }}+\phi_{2} \times \mathrm{D}_{\mathrm{i}}^{\text {SECEXIT }}+\gamma_{4} \mathrm{X}_{i}+\varepsilon_{i}
$$

The dependent variable XSMULT EXIT is a measure of valuation at the time of the exit using either

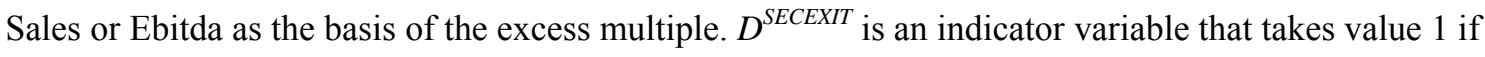
the LBO is exited through a sale to another PE fund and 0 otherwise. As before, the coefficient $\beta_{4}$ of the interaction term Sell Pressure $\times D^{S E C}$ is the coefficient of interest. The matrix $\mathbf{X}$ includes control variables measured at the time of exit, as in subsection 4.1, and we also replace TEV (part of the multiple) with an instrument for deal size, represented by Buyer Size. All specifications include industry- and year-dummies and year-clustered standard errors.

The regression results are reported in Table 6 . We find that $\beta_{4}$, the coefficient of our sale pressure index for secondary exits is negative and marginally statistically significant (coefficient 0.222, t-stat. -1.69) in Panel A, when we use the Exit Excess Sales Multiple as dependent variable, but statistically insignificant in Panel B, when we use the Exit Excess Ebitda Multiple. The negative sign 
in Panel A implies that sellers under pressure exit at lower multiples in secondary deals than other sellers but the impact of the sale pressure on valuations is weak. Out of the three individual components, the interaction Late Seller $\times D^{\text {SECEXIT }}$ is statistically significant at the $10 \%$ level (columns 2 through 4) in both panels, while other terms are not consistently statistically significant. The interaction Sell Pressure $\times D^{\text {SECEXIT }}$ also loses statistical significance in our extended specification (column 5). Within the set of secondary exits, a statistically significant association exists between selling pressure and valuation using the sales multiple but not for the Ebitda multiple. We conclude that there is evidence that the pressure to exit affects exit valuation in secondary deals but this evidence is weaker and the effect is driven by the seller fund's age.

\section{Further analyses}

\subsection{Buyer or Seller Pressure: Which effect dominates?}

Our empirical analysis documented that less reputable PE funds sitting on a lot of unspent capital late in their investment period are more likely to do secondary buyouts and when they do, they invest at higher valuation. We also found that less reputable PE funds late in their harvesting period with little recent exit activity are more likely to exit via secondary sale and these deals close at somewhat lower valuation - though the evidence for the latter is weaker. The natural next question to ask is at what valuation multiples the secondary transactions close when buyers under pressure to invest meet with sellers under pressure to exit. When the buyer pays more, the seller benefits from the higher valuation and when the seller exits at lower valuation, the buyer gains. Our findings that pressured buyers buy at higher valuations and pressured sellers sell at lower valuations do not provide any guidance when it comes to secondary transactions between pressured sellers and buyers as the two findings are mutually exclusive. Both the agency story and our evidence on valuation suggest that sellers probably have the upper hand but further empirical analysis is needed to establish whether this is indeed the case.

Hence, we estimate a model for the valuation of secondary LBOs within the subsample of exits for which we have information about buyers' status, sellers' status, and deal valuations. We include as explanatory variables our Buy Pressure and Selling Pressure indexes simultaneously, as well as the control variables used in subsection 4.2 above.

The results, displayed in Table 7, show that the coefficient of Buy Pressure is positive and statistically significant at the $5 \%$ or $10 \%$ across all specifications. This result holds irrespective of the multiples used. In contrast, the Sell Pressure variable is negative and statistically significant only once, for the Sales multiple (Panel A, column 1). For the individual components of our Sell Pressure 
index we find that deals involving late sellers seem to display lower prices, but our Buy Pressure index is still statistically significant even in this case.

We conclude that in these secondary transactions pressured buyers pay higher valuations and the selling funds seem to have most of the bargaining power. This finding supports of our agency hypothesis that pressured buyers desperate to spend their dry powder to lock in their management fee for the remaining years and to attract LP investors for their next fund are bidding most aggressively to stay in business and willing to give concessions even to pressured sellers.

\subsection{Secondary Deals, Leverage, and Pressure}

We further investigate the hypothesis that the buy and sell pressure of the participating funds is an important force driving secondary buyouts and analyze the deal leverage in secondary transactions.

Concerning secondary deals, on the supply side lenders face lower information costs for companies that are already LBO targets, and are presumably willing to lend more to firms that were able to carry more debt in their first LBO. On the demand side, an SBO presents an opportunity to lever up further, for example if it turns out that given the debt capacity of the portfolio company is hugher than was anticipated in the first LBO deal. Also, as shown in Axelson et al. (2012), Bonini (2012), Wang (2012), and Achleitner et al. (2012), SBO activity is generally high when debt financing costs are low. Hence, one would be inclined to predict that secondary deals are more levered on

average. Interestingly, however, the existing evidence that on-deal leverage of SBOs is higher is at best mixed. Among the previous papers investigating SBOs, only Achleitner and Figge (2011) document higher deal leverage in SEOs whereas Bonini (2012) and Wang (2012) reports less.

Our prediction for the impact of buy pressure on deal leverage is the opposite. In general, funds under buy pressure are longing to put their capital to use. They might be willing to execute a deal with relative more equity than other PE buyers, both because their opportunity cost of doing so is lower and because their primary motive for executing the deal is to spend their dry powder and thereby secure their management fee and increase their chance to raise a new fund.

Combining both predictions, we expect that the impact of buy pressure on deal leverage in secondary deals to be ambiguous. As discussed before, secondary deals in general would lead to higher deal leverage whereas buy pressure would result in higher equity participation by the PE fund and, consequently, to lower deal leverage. We expect, therefore, the interaction term of buy pressure and secondary deals to show that leverage is higher in secondary deals under pressure than in primary deals under pressure. 
Hence, we investigate the relation between deal pressure and deal leverage for secondary deals by estimating regression models similar to those used to study the impact of valuation at entry. The dependent variable is Deal Leverage, the ratio of Senior Debt to Enterprise Value at the onset of an LBO deal. ${ }^{12}$ Information on Senior Debt, defined as the sum of all term debt facilities used in the deal, is obtained from multiple sources including Capital IQ, DealScan, Dealogic, and company filings in the case of public-to-private deals. We make slight changes to the specification we use, namely by using High Yield Spread as a control in all specifications, given that credit spreads have been found to be the most important determinant of LBO debt levels (e.g. Axelson et al., 2012).

Table 8 reports the results. In columns 1 and 2, the entire sample of deals with available debt information is used and hence the main coefficient of interest is the interaction term Buy Pressure $\times$ Secondary. In columns 3 and 4 , we restrict ourselves to secondary deals and the main coefficient of interest is the Buy Pressure variable.

Overall, we find that LBO debt levels are negatively correlated with deal size and credit spreads (t-statistics -4.3 and -2.3 , respectively), and positively correlated with past LBO activity (tstatistic 3.7, from column 2). When controls for these characteristics are introduced, secondary LBOs have similar debt levels as other deals (the coefficient of secondary is indistinguishable from zero), in line with the picture that emerges from earlier literature. There seem to be reasons, only imperfectly captured by Buy Pressure, why buyers in secondary deals prefer not to increase leverage.

However, Buy Pressure exhibits a negative sign that is marginally significant at the $10 \%$ level in the extended specification. This indicates that funds under pressure tend to use more equity in the deals they make as predicted by the buy pressure hypothesis. Moreover, the interaction term is statistically significant highlighting that the opposite influences of the two underlying variables affect deal leverage. Consistent with the prediction above that the effect of the credit supply in secondary deals and the pressure to invest unspent capital pulls deal leverage in opposite directions, - the interaction term of secondary deals and buy pressure shows that the impact of pressure is weaker in secondary deals than in primary dealsis not statistically significant but its sign is positive, consistent with our prediction that credit supply and demand in secondary deals and the pressure to invest unspent capital pull deal leverage in opposite directions.

When we limit ourselves to the sample of secondary deals (columns 3 and 4), we find that Buy Pressure is significant at the 5\% level when all controls are included (t-statistic -1.84). This finding supports the view that in secondary deals buyers under pressure are motivated to accelerate the spending of their dry powder and hence they execute deals with more equity and lower debt levels.

\footnotetext{
${ }^{12}$ We have also repeated the analysis using other definitions of deal leverage, namely the ratio of Senior Debt to EBITDA and the ratio of Senior Debt to total Assets. Conclusions are similar, namely that Buy Pressure is either uncorrelated or weakly negatively correlated with the use of leverage in secondary LBOs.
} 


\section{Conclusion}

This paper tests hypotheses on how PE contracts affect deal making incentives over the lifecycles of PE funds. We focus on secondary buyouts, an increasingly important segment of the LBO market where PE funds exit the target firm by selling to other PE funds. Independent estimates (confirmed in our data) suggest that SBOs account for more than $20 \%$ (and growing) of deal flow ${ }^{13}$. Previous studies in the literature analyzing secondary deals concluded that they are mainly driven by loose debt market and tighter equity market conditions ${ }^{14}$. In contrast, we posit that the PE fund incentives are likely to impact the choice of investment/exit. We conjecture that PE funds are more likely to do a secondary buyout if they are under pressure to invest (exit) and the transaction will be priced at higher (lower) valuations depending on whether the buyer (seller) is under deal pressure. We propose an index for the pressure to invest and another index for the pressure to exit. We test our hypotheses using an almost complete set of LBO deals in both U.S. and Europe from 1980 through 2010 (9,771 LBO deals, out of which we able to trace 4,328 exit routes and dates). We find robust support for these hypotheses, both for pressured buyers and sellers for the probability of SBOs as well as the impact on valuation, even after controlling for market conditions. We also find that when pressured buyers meet pressured sellers in a secondary transaction, it is the seller who has most of the bargaining power, since pressured buyers desperate to spend their dry powder to lock in their management fee for the remaining years and to attract LP investors for their next fund are bidding most aggressively to stay in business and willing to give large concessions even to pressured sellers.

For future research additional insights can be obtained by access to data on actual contractual provisions between GPs and LPs of PE funds (which we do not currently have) assuming sufficient contractual variations exist in the data for the terms that drive the pressure to invest and exit. While such data will unlikely be accessible for the universe of LBO transactions we studied here and will likely cover only one or a few LPs with limited contractual variations, further analysis of actual contractual terms driving investment and exit choices would nevertheless be an interesting new avenue for future research.

\footnotetext{
${ }^{13}$ See Preqin Buyout Deals Analyst, 2011.

${ }^{14}$ See Wang (2012), Jenkinson and Sousa (2012) amongst others.
} 


\section{References}

Acharya, V., O. Gottschalg, M. Hahn and C. Kehoe, 2013, Corporate governance and value creation: evidence from private equity, Review of Financial Studies, 26(2), 368-402.

Achleitner, A., O. Bauer, C. Figge and E. Lutz., 2012, Exit of last resort? Empirical evidence on the returns and drivers of secondary buyouts as private equity exit, mimeo, Center for Entrepreneurial and Financial Studies (CEFS), TUM Business School.

Achleitner, A. and C. Figge, 2011, Private Equity Lemons? Evidence on Value Creation in Secondary Buyouts, mimeo, Center for Entrepreneurial and Financial Studies (CEFS), TUM Business School.

Axelson, U., T. Jenkinson, P. Strömberg, and M. Weisbach, 2012, Borrow cheaply, buy high? Determinants of Leverage and Pricing in Buyouts, forthcoming, Journal of Finance.

Axelson, U., P. Strömberg, and M.Weisbach, 2009, Why are buyouts levered? The financial structure of private equity funds, Journal of Finance, 64, 1549-1582.

Barrot, J.-N., 2012, Investor Horizon and Innovation: Evidence from Private Equity Funds, mimeo, MIT Sloan.

Berk, J.B. and R.C. Green, 2004, Mutual Fund Flows and Performance in Rational Markets, Journal of Political Economy, 112(6), 1269-1295.

Boucly, Q., D. Sraer and D. Thesmar, 2011, Growth LBOs, Journal of Financial Economics, 102, 432-453.

Bonini, S., 2012, Secondary Buyouts, mimeo, Department of Finance, Bocconi Unversity.

Chung, J.-W., 2010, Leveraged buyouts of private companies, Ohio State University working paper.

Chung, J.-W., B. Sensoy, L. Stern and M. Weisbach, 2010, Pay for Performance from Future Fund Flows: The Case of Private Equity, mimeo, Ohio State University.

Cornelli, F., and O. Karakas, 2010, Is the corporate governance of LBOs effective?, mimeo, London Business School.

Cotter, J. F., and S. W. Peck, 2001, The structure of debt and active equity investors: The case of the buyout specialist, Journal of Financial Economics 59 101-147.

Degeorge, F., J. Martin and L. Phalippou, 2013, Is the rise of secondary buyouts good news for investors?, mimeo, University of Lugano.

Demiroglu C., and C. James, 2010, The role of private equity group reputation in LBO financing, Journal of Financial Economics 96, 306-330.

Dow, J. and G. Gorton, 1997, Noise trading, delegated portfolio management, and economic welfare, Journal of Political Economy 105, 1024-1050.

Franzoni, F., E. Nowak, and L. Phalippou, 2012, Private Equity Performance and Liquidity Risk, Journal of Finance 67, forthcoming. 
Guo, S., E. S. Hotchkiss, and W. Song, 2011, Do buyouts (still) create value?, Journal of Finance 66, 479-517.

Gurung, A., and J. Lerner (co-eds.), 2008, The Global Economic Impact of Private Equity Report, World Economic Forum.

Jensen, M.,1986, Agency costs of free cash-flow, corporate finance and takeovers, American Economic Review 76 323-329.

Jensen, M.,1993. The modern industrial revolution, exit, and the failure of internal control systems, Journal of Finance 48, 831-880.

Jensen, M., and W. Meckling, 1976, Theory of the firm: managerial behavior, agency costs and ownership structure, Journal of Financial Economics 3, 305-360.

Jenkinson, T., and M. Sousa, 2011, Keep taking the private equity medicine?, mimeo, Said Business School, University of Oxford.

Jenkinson, T., and M. Sousa, 2012, Why do Private Equity firms sell to each other?, mimeo, Said Business School, University of Oxford.

Kandel, E., D. Leshchinskii and H. Yuklea (2011), VC Funds: Aging Brings Myopia, Journal of Financial and Quantitative Analysis 46, 431-457.

Kaplan S., 1989a, The Effects of Management Buyouts on Operating Performance and Value, Journal of Financial Economics 24 217-254.

Kaplan S., 1989b, Management buyouts: Evidence on taxes as source of value, Journal of Finance 44, 611-632.

Kaplan S., and J. Stein, 1993, The evolution of buyout pricing and financial structure in the 1980s, Quarterly Journal of Economics 108, 313-357.

Lehn, K. and A. Poulsen, 1989, Free cash flow and the sources of gains in leveraged buyout transactions, Journal of Finance 44, 771-787.

Metrick, A., and A. Yasuda, 2010, The Economics of Private Equity Funds, Review of Financial Studies 23, 2303-2341.

Muscarella, C. and M. Vetsuypens, 1990, Efficiency and organizational structure: a study of reverse LBOs, Journal of Finance 45, 1389-1413.

Officer, M., O. Ozbas and B. Sensoy, 2010 Club deals in leveraged buyouts, Journal of Financial Economics 98, 214-240.

Phalippou, L. and O. Gottschalg, 2009, The performance of Private Equity Funds, Review of Financial Studies 22, 1747-1776.

Schlingemann, F. , R. Stulz, R. Walkling, 2002, Divestitures and the liquidity of the market for corporate assets, Journal of Financial Economics 64, 117-144.

Smith, A., 1990, Corporate Ownership Structure and Performance: The Case of Management Buyouts, Journal of Financial Economics 27 143-164.

Strömberg, P., 2008, The new demography of private equity, World Economic Forum: The 
Global Economic Impact of Private Equity Report.

Wang, Y., 2012, Secondary Buyouts: Why Buy and at What Price?, Journal of Corporate Finance 18, 1306-1325 
Table 1

\section{Summary Statistics}

This table presents summary statistics for the sample used in this study. Panel A presents the summary statistics data for our firm-level panel. Secondary is an indicator variable with value 1 if the seller in a deal is a PE fund. Imputed TEV of the target firm is the sum of the target's equity market value valued at the LBO offer price, and the target's net debt (financial debt minus cash and marketable securities). For transactions without deal value information, we compute an estimate of deal value using the methodology of Stromberg (2008) (see Appendix for further details). Mgmt. Participation is an indicator variable equal to 1 if at least one member of the management team of the target is referenced as an investor in the LBO transaction. U.S. target is equal to 1 if the target is headquartered in the US. Syndicated is an indicator variable equal to 1 , if there is more than one buyer. Fund belonging to the same fund family are counted as a single buyer. HY Spread is the difference, at the time of the LBO, between the Barclays High Yield Composite index and the Barclays average corporate AAA corporate bond rate. The index is only available after 1987. Cold IPO Market is an indicator variable equal to 1 if the IPO market is 'cold' at the time of the LBO. To define a cold [hot] IPO market, we compute the aggregate deal value of IPOs taking place in the same geography (U.S. or Europe), same Fama-French 12- industry classification, and year as the target firm, and check if this value is lower [higher] than the geography- and industry-level time series mean. Dry Powder is an indicator variable equal to 1 if the buyer is above median in terms of fund raising and below median in terms of deal activity. These criteria are computed as follows. First, for each PE fund family and year, we calculate the aggregate funds raised in the past 3 years, and the corresponding median across fund families in that year. Second, for each PE fund family and year, we compute the aggregate dollar value of all investment made during the past three years, and its respective median across fund families in that year. Late Buyer is an indicator variable with value 1 if the buyer's most recent fund at the time of the deal is at the end of its investment period (4 to 6 years after inception). Lack of Reputation is an indicator variable equal to 1 if the buyer is not among the PEI Media Top 50 PE firms. Buyer Pressure is the sum of variables Dry Powder, Late Buyer, and Lack of Reputation. Affiliated is an indicator variable equal to 1 , if the buyer is affiliated to a financial institution or government agency. Novice is an indicator variable with value 1 if the buyer is a PE fund family with 3 funds or less under management at the time of the LBO deal. Panel $B$ presents the variables used to measure valuation of the deal at the time of entry. Sales Multiple is the ratio between TEV and latest available yearly sales for the target firm at the time of the LBO. This variable only takes non-missing values when deal value is known. Excess Sales Mutiple is the difference between the target's Sales Multiple and a valuation benchmark constructed as a follows. For every year, geography (U.S. versus Europe), industry (Fama-French 12-industry classification) and public status (public or private), we compute the median sales multiple for all merger transactions with value larger than 1 million dollars involving a majority stake over the previous two years relative to the date of the LBO. Ebitda Mutiple is the ratio between TEV and Ebitda for the target firm at the time of the LBO. This variable only takes non-missing values when deal value is known. Excess Ebitda multiple is the difference between the target's Ebitda Multiple and the benchmark, the median Ebitda multiple for all merger transactions with value larger than 1 million dollars involving a majority stake over the previous two years in the same geography (U.S. versus Europe), industry (Fama-French 12-industry classification) and public status (public or private) as the target LBO firm. Panel C describes the characteristics at the time of exit. Secondary Exit is an indicator variable equal to 1 , if the exit route of the LBO is a sale to another PE fund or group of PE funds. Add-ons is equal to 1, if there were significant acquisitions during the time that the buyer held the target firm in its portfolio. We define acquisitions as significant if there are three or more acquisitions made by the target company during this period or if they represent a cumulative dollar value of $5 \%$ or more of the original LBO deal value. Stage is the number of years elapsed since fund raising for the youngest fund in the PE fund family whose investment period overlaps with the LBO deal date (that is. whose deal date falls within years 1 through 6 of the lifetime of the fund). Last Exit is equal to 1 if three or more years have elapsed since the PE fund family last exited an LBO deal. Late Seller is an indicator variable with value 1, if the sale takes place in years 9 or 10 of the PE fund family's oldest active fund (i.e. less than 11 years old). Seller Pressure is the sum of variables Exit Pressure, Late Seller, and Lack of Reputation. Down Exit is equal to 1 if exit route of the LBO is a sale to existing management, a distressed merger transaction, or bankruptcy. M \& A Exit is equal to 1, if exit is through sale to a corporate buyer. IPO Exit is equal to 1 if exit is an equity listing on public markets. Panel D describes the valuation variables at the time of exit (see Panel B above for a description of the variables). All monetary values are measured in real December 2010 U.S. dollars, after conversion at historical exchange, rates. 
Table 1

Summary Statistics (cont.)

\begin{tabular}{lcccccc}
\hline \multicolumn{1}{c}{ Variable } & $\mathrm{N}$ & Mean & Std. Dev. & $\mathrm{Q} 1$ & Median & $\mathrm{Q} 3$ \\
\hline Secondary & 9,771 & 0.165 & 0.371 & 0 & 0 & 0 \\
Imputed TEV & 9,771 & 281.8 & 1283.4 & 41.6 & 87.5 & 186.2 \\
Mgmt. participation & 9,771 & 0.440 & 0.496 & 0 & 0 & 1 \\
U.S. target & 9,771 & 0.511 & 0.500 & 0 & 1 & 1 \\
Syndicated & 9,771 & 0.511 & 0.500 & 0 & 1 & 1 \\
HY Spread & 9,588 & 3.809 & 2.063 & 2.380 & 3.030 & 4.550 \\
Cold IPO Market & 9,766 & 0.523 & 0.499 & 0 & 1 & 1 \\
& & & & & & \\
Dry Powder & 9,771 & 0.232 & 0.422 & 0 & 0 & 0 \\
Late Buyer & 9,771 & 0.213 & 0.410 & 0 & 0 & 0 \\
Lack of Reputation & 9,771 & 0.763 & 0.425 & 1 & 1 & 1 \\
Buy Pressure & 9,771 & 1.209 & 0.724 & 1 & 1 & 2 \\
Affiliated & 9,771 & 0.199 & 0.399 & 0 & 0 & 0 \\
Novice & 9,770 & 0.507 & 0.500 & 0 & 1 & 1 \\
& & & & & & \\
Divisional & 9,771 & 0.194 & 0.395 & 0 & 0 & 0 \\
Financial seller & 9,771 & 0.055 & 0.228 & 0 & 0 & 0 \\
Public to private & 9,771 & 0.051 & 0.219 & 0 & 0 & 0 \\
Private to private & 9,771 & 0.536 & 0.499 & 0 & 1 & 1 \\
& & & & & & \\
\hline
\end{tabular}

\begin{tabular}{lcccccc}
\hline \multicolumn{7}{c}{ Panel B. LBO Valuation at Entry } \\
\hline \multicolumn{1}{c}{ Variable } & $\mathrm{N}$ & Mean & Std. Dev. & $\mathrm{Q} 1$ & Median & Q3 \\
\hline TEV & 1,399 & 892.1 & 2773.9 & 60.2 & 211.4 & 703.8 \\
Sales Multiple & 1,399 & 1.397 & 1.247 & 0.592 & 1.021 & 1.761 \\
Excess Sales Multiple & 1,399 & 0.283 & 1.173 & -0.393 & 0.027 & 0.656 \\
EBITDA Multiple & 684 & 9.397 & 4.809 & 6.288 & 8.404 & 11.514 \\
Excess EBITDA Multiple & 684 & -1.352 & 5.822 & -3.931 & -1.514 & 1.182
\end{tabular}


Table 1

Summary Statistics (cont.)

\begin{tabular}{lcccccc}
\hline \multicolumn{1}{c}{ Panel C. LBO characteristics at Exit } & & \\
\hline \multicolumn{1}{c}{ Variable } & $\mathrm{N}$ & Mean & Std. Dev. & $\mathrm{Q} 1$ & Median & $\mathrm{Q} 3$ \\
\hline Secondary Exit & 4,328 & 0.294 & 0.456 & 0 & 0 & 1 \\
Add-ons & 4,328 & 0.113 & 0.317 & 0 & 0 & 0 \\
Stage & 4,328 & 2.306 & 1.346 & 1 & 2 & 3 \\
Affiliated & 4,328 & 0.186 & 0.389 & 0 & 0 & 0 \\
Novice & 4,165 & 0.374 & 0.484 & 0 & 0 & 1 \\
HY Spread & 4,144 & 3.754 & 2.174 & 2.350 & 2.920 & 4.545 \\
Cold IPO Market & 4,328 & 0.565 & 0.496 & 0 & 1 & 1 \\
& & & & & & \\
Last Exit & 4,328 & 0.104 & 0.306 & 0 & 0 & 0 \\
Late Seller & 4,328 & 0.126 & 0.332 & 0 & 0 & 0 \\
Lack of Reputation & 4,328 & 0.688 & 0.463 & 0 & 1 & 1 \\
Sell Pressure & 4,328 & 0.919 & 0.691 & 0 & 1 & 1 \\
Affiliated & 4,328 & 0.186 & 0.389 & 0 & 0 & 0 \\
Novice & 4,165 & 0.374 & 0.484 & 0 & 0 & 1 \\
& & & & & & \\
Down Exit & 4,328 & 0.100 & 0.300 & 0 & 0 & 0 \\
M\&A Exit & 4,328 & 0.479 & 0.500 & 0 & 0 & 1 \\
IPO Exit & 4,328 & 0.126 & 0.332 & 0 & 0 & 0 \\
& & & & & & \\
\hline \multicolumn{1}{c}{ Variable } & Panel D. LBO Valuation at Exit & & & \\
\hline Sales Multiple & $\mathrm{N}$ & Mean & Std. Dev. & Q1 & Median & Q3 \\
\hline Excess Sales Multiple & 1,127 & 1.860 & 1.560 & 0.829 & 1.443 & 2.374 \\
EBITDA Multiple & 1,127 & 0.756 & 1.423 & -0.155 & 0.405 & 1.251 \\
Excess EBITDA Multiple & 613 & 10.840 & 5.141 & 7.390 & 9.468 & 13.643 \\
\hline & 0.821 & 6.061 & -1.968 & 0.341 & 3.826 \\
\hline
\end{tabular}


Table 2

\section{Univariate Comparisons: Secondary Deals vs. Non-Secondary Deals}

This table presents univariate tests of significance of LBO characteristics and valuation between Secondary and Non-secondary deals. A LBO deal is defined as Secondary if the seller in the deal is a PE fund and Non-secondary otherwise. Panel A presents the tests for our firm-level panel. Imputed TEV of the target firm is the sum of the target's equity market value valued at the LBO offer price, and the target's net debt (financial debt minus cash and marketable securities). For transactions without deal value information, we compute an estimate of deal value using the methodology of Stromberg (2008) (see Appendix for further details). Mgmt. Participation is an indicator variable equal to 1 if at least one member of the management team of the target is referenced as an investor in the LBO transaction. U.S. target is equal to 1 if the target is headquartered in the US. Syndicated is an indicator variable equal to 1 , if there is more than one buyer. Fund belonging to the same fund family are counted as a single buyer. HY Spread is the difference, at the time of the LBO, between the Barclays High Yield Composite index and the Barclays average corporate AAA corporate bond rate. The index is only available after 1987. Cold IPO Market is an indicator variable equal to 1 if the IPO market is 'cold' at the time of the LBO. To define a cold [hot] IPO market, we compute the aggregate deal value of IPOs taking place in the same geography (U.S. or Europe), same Fama-French 12-code industry, and year as the target firm, and check if this value is lower [higher] than the geographyand industry-level time series mean. Dry Powder is an indicator variable equal to 1 if the buyer is above median in terms of fund raising and below median in terms of deal activity. These criteria are computed as follows. First, for each PE fund family and year, we calculate the aggregate funds raised in the past 3 years, and the corresponding median across fund families in that year. Second, for each PE fund family and year, we compute the aggregate dollar value of all investment made during the past three years, and its respective median across fund families in that year. Late Buyer is an indicator variable with value 1 if equal to 1 if the buyer's most recent fund at the time of the deal is at the end of its investment period (4 to 6 years after inception). Lack of Reputation is an indicator variable equal to 1 if the buyer is not among the PEI Media Top 50 PE firms. Buyer Pressure is the sum of variables Dry Powder, Late Buyer, and Lack of Reputation. Affiliated is an indicator variable equal to 1 , if the buyer is affiliated to a financial institution or government agency. Novice is an indicator variable with value 1 if the buyer is a PE fund family with 3 funds or less under management at the time of the LBO deal. Panel B presents the variables used to measure valuation of the deal at the time of entry. Sales Multiple is the ratio between TEV and latest available yearly sales for the target firm at the time of the LBO. This variable only takes non-missing values when deal value is known. Excess Sales Mutiple is the difference between the target's Sales Multiple and a valuation benchmark constructed as a follows. For every year, geography (U.S. versus Europe), industry (Fama-French 12-industry classification) and public status (public or private), we compute the median sales multiple for all merger transactions with value larger than 1 million dollars involving a majority stake over the previous two years relative to the date of the LBO. Ebitda Mutiple is the ratio between TEV and Ebitda for the target firm at the time of the LBO. This variable only takes non-missing values when deal value is known. Excess Ebitda multiple is the difference between the target's Ebitda Multiple and the benchmark, the median Ebitda multiple for all merger transactions with value larger than 1 million dollars involving a majority stake over the previous two years in the same geography (U.S. versus Europe), industry (Fama-French 12-industry classification) and public status (public or private) as the target LBO firm. All monetary values are measured in real December 2010 U.S. dollars, after conversion at historical exchange, rates. T-test for differences in means and medians (where applicable) are reported, the symbols $* * *, * *, *$ denote significance at $1 \%, 5 \%$ and $10 \%$ respectively.

\begin{tabular}{|c|c|c|c|c|c|c|c|c|}
\hline \multicolumn{9}{|c|}{ Panel A. Univariate Comparisons: LBO characteristics } \\
\hline \multirow{3}{*}{$\frac{\text { Variable }}{\text { Imputed TEV }}$} & \multicolumn{3}{|c|}{ Secondary Deals } & \multicolumn{5}{|c|}{ Non-secondary Deals } \\
\hline & \multirow{2}{*}{$\frac{\mathrm{N}}{1,611}$} & \multirow{2}{*}{$\begin{array}{c}\text { Mean } \\
361.9\end{array}$} & \multirow{2}{*}{$\frac{\text { Median }}{212.8}$} & \multirow{2}{*}{$\frac{\mathrm{N}}{8,160}$} & \multicolumn{2}{|c|}{ Mean } & \multicolumn{2}{|c|}{ Median } \\
\hline & & & & & 265.9 & $* * *$ & 74.5 & $* * *$ \\
\hline Mgmt. participation & 1,611 & 0.503 & 1 & 8,160 & 0.427 & $* * *$ & 0 & \\
\hline U.S. target & 1,611 & 0.472 & 0 & 8,160 & 0.518 & $* * *$ & 1 & \\
\hline Syndicated & 1,611 & 0.549 & 1 & 8,160 & 0.503 & $* * *$ & 1 & \\
\hline HY Spread & 1,597 & 3.494 & 2.830 & 7,991 & 3.872 & $* * *$ & 3.210 & $* * *$ \\
\hline Cold IPO Market & 1,611 & 0.589 & 1 & 8,155 & 0.510 & $* * *$ & 1 & \\
\hline Dry Powder & 1,611 & 0.262 & 0 & 8,160 & 0.226 & $* * *$ & 0 & \\
\hline Late Buyer & 1,611 & 0.239 & 0 & 8,160 & 0.208 & $* * *$ & 0 & \\
\hline Lack of Reputation & 1,611 & 0.779 & 1 & 8,160 & 0.760 & & 1 & \\
\hline Buy Pressure & 1,611 & 1.280 & 1 & 8,160 & 1.194 & $* * *$ & 1 & \\
\hline Affiliated & 1,611 & 0.233 & 0 & 8,160 & 0.192 & $* * *$ & 0 & \\
\hline Novice & 1,611 & 0.400 & 0 & 8,160 & 0.528 & $* * *$ & 1 & \\
\hline \multicolumn{9}{|c|}{ Panel B. Univariate Comparisons: LBO Valuation at Entry } \\
\hline & \multicolumn{3}{|c|}{ Secondary Deals } & \multicolumn{5}{|c|}{ Non-secondary Deals } \\
\hline Variable & $\mathrm{N}$ & Mean & Median & $\mathrm{N}$ & Mean & & Med & \\
\hline TEV & 337 & 650.6 & 329.5 & 1,061 & 968.8 & $*$ & 184.5 & $* * *$ \\
\hline Sales Multiple & 337 & 1.604 & 1.333 & 1,062 & 1.331 & $* * *$ & 0.964 & $* * *$ \\
\hline Excess Sales Multiple & 337 & 0.607 & 0.325 & 1,062 & 0.180 & $* * *$ & -0.058 & $* * *$ \\
\hline EBITDA Multiple & 144 & 10.164 & 9.509 & 540 & 9.193 & $* *$ & 8.022 & $* * *$ \\
\hline Excess EBITDA Multiple & 144 & -0.411 & -0.261 & 540 & -1.603 & $* *$ & -1.851 & $* * *$ \\
\hline
\end{tabular}


Table 3

\section{Likelihood of a Secondary Deal}

This table presents results of a logistic regression, where the dependent variable is a secondary deal, an indicator variable with value 1 if the seller in a deal is a PE firm. The explanatory variables are Buy Pressure, the sum of variables Dry Powder, Late Buyer, and Lack of Reputation. Dry Powder is an indicator variable equal to 1 if the buyer is above median in terms of fund raising and below median in terms of deal activity, computed as follows: First, for each PE fund family and year, we calculate the aggregate funds raised in the past 3 years, and the corresponding median across fund families in that year; second, for each PE fund family and year, we compute the aggregate dollar value of all investment made during the past three years, and its respective median across fund families in that year. Late Buyer is an indicator variable with value 1 if equal to 1 if the buyer's most recent fund at the time of the deal is at the end of its investment period (4 to 6 years after inception). Lack of Reputation is an indicator variable equal to 1 if the buyer is not among the PEI Media Top 50 PE firms. Imputed TEV of the target firm is the sum of the target's equity market value valued at the LBO offer price, and the target's net debt (financial debt minus cash and marketable securities). For transactions without deal value information, we compute an estimate of deal value using the methodology of Stromberg (2008) (see Appendix for further details). Mgmt. Participation is an indicator variable equal to 1 if at least one member of the management team of the target is referenced as an investor in the LBO transaction. U.S. target is equal to 1 if the target is headquartered in the US. Syndicated is an indicator variable equal to 1 , if there is more than one buyer. Fund belonging to the same fund family are counted as a single buyer. Affiliated is an indicator variable equal to 1 , if the buyer is affiliated to a financial institution or government agency. Novice is an indicator variable with value 1 if the buyer is a PE fund family with 3 funds or less under management at the time of the LBO deal. HY Spread is the difference, at the time of the LBO, between the Barclays High Yield Composite index and the Barclays average corporate AAA corporate bond rate. The index is only available after 1987. Cold IPO Market is an indicator variable equal to 1 if the IPO market is 'cold' at the time of the LBO. To define a cold [hot] IPO market, we compute the aggregate deal value of IPOs taking place in the same geography (U.S. or Europe), same Fama-French 12-code industry, and year as the target firm, and check if this value is lower [higher] than the geography- and industry-level time series mean. All monetary values are measured in real December 2010 U.S. dollars, after conversion at historical exchange, rates. Regressions include industry dummies and yearly dummies. Industries are defined using the Fama and French (1992) classification. We use standard errors clustered by deal year to accommodate heteroskedasticity and within-year autocorrelation. t-statistics are reported in parentheses and $* * *, * *, *$ denote significance at $1 \%, 5 \%$ and $10 \%$.

\begin{tabular}{|c|c|c|c|c|c|c|c|c|c|c|c|c|}
\hline \multicolumn{13}{|c|}{ Dependent variable: Secondary Deal Indicator } \\
\hline & $(1)$ & & $(2)$ & & (3) & & (4) & & $(5)$ & & $(6)$ & \\
\hline Buy Pressure & $\begin{array}{l}0.261 \\
(4.82)\end{array}$ & $* * *$ & & & & & & & $\begin{array}{l}0.260 \\
(4.49)\end{array}$ & $* * *$ & $\begin{array}{l}0.225 \\
(3.82)\end{array}$ & *** \\
\hline Dry Powder & & & $\begin{array}{l}0.145 \\
(2.22)\end{array}$ & $* *$ & & & & & & & & \\
\hline Late Buyer & & & & & $\begin{array}{l}0.127 \\
(2.80)\end{array}$ & $* * *$ & & & & & & \\
\hline Lack of Reputation & & & & & & & $\begin{array}{l}0.636 \\
(5.09)\end{array}$ & $* * *$ & & & & \\
\hline Imputed TEV & $\begin{array}{c}0.706 \\
(20.48)\end{array}$ & $* * *$ & $\begin{array}{c}0.667 \\
(19.38)\end{array}$ & $* * *$ & $\begin{array}{c}0.673 \\
(19.88)\end{array}$ & $* * *$ & $\begin{array}{c}0.761 \\
(18.44)\end{array}$ & $* * *$ & $\begin{array}{c}0.708 \\
(18.51)\end{array}$ & $* * *$ & $\begin{array}{c}0.298 \\
(10.58)\end{array}$ & *** \\
\hline Mgmt. Participation & $\begin{array}{l}0.468 \\
(6.15)\end{array}$ & $* * *$ & $\begin{array}{l}0.488 \\
(6.06)\end{array}$ & $* * *$ & $\begin{array}{l}0.485 \\
(6.13)\end{array}$ & $* * *$ & $\begin{array}{l}0.448 \\
(6.28)\end{array}$ & $* * *$ & $\begin{array}{l}0.451 \\
(5.91)\end{array}$ & $* * *$ & $\begin{array}{l}0.482 \\
(3.44)\end{array}$ & $* * *$ \\
\hline U.S. Target & $\begin{array}{l}-0.256 \\
(-3.14)\end{array}$ & *** & $\begin{array}{c}-0.22 \\
(-2.57)\end{array}$ & ** & $\begin{array}{l}-0.231 \\
(-2.67)\end{array}$ & *** & $\begin{array}{l}-0.283 \\
(-3.39)\end{array}$ & $* * *$ & $\begin{array}{l}-0.222 \\
(-2.46)\end{array}$ & ** & $\begin{array}{c}-0.28 \\
(-3.15)\end{array}$ & $* * *$ \\
\hline Syndicated & $\begin{array}{l}-0.132 \\
(-1.87)\end{array}$ & $*$ & $\begin{array}{l}-0.114 \\
(-1.58)\end{array}$ & & $\begin{array}{l}-0.113 \\
(-1.60)\end{array}$ & & $\begin{array}{l}-0.146 \\
(-2.09)\end{array}$ & $* *$ & $\begin{array}{l}-0.133 \\
(-1.94)\end{array}$ & $*$ & $\begin{array}{l}-0.096 \\
(-0.92)\end{array}$ & \\
\hline Affiliated & & & & & & & & & $\begin{array}{l}0.137 \\
(2.17)\end{array}$ & $* *$ & & \\
\hline Novice & & & & & & & & & $\begin{array}{c}0.004 \\
0.06\end{array}$ & & & \\
\hline HY Spread & & & & & & & & & $\begin{array}{l}-0.028 \\
(-1.67)\end{array}$ & $*$ & & \\
\hline Cold IPO Market & & & & & & & & & $\begin{array}{l}-0.039 \\
(-0.32)\end{array}$ & & & \\
\hline Intercept & $\begin{array}{c}-8.032 \\
(-14.31)\end{array}$ & $* * *$ & $\begin{array}{c}-7.686 \\
(-14.09)\end{array}$ & $* * *$ & $\begin{array}{c}-7.684 \\
(-14.09)\end{array}$ & $* * *$ & $\begin{array}{c}-8.443 \\
(-13.90)\end{array}$ & $* * *$ & $\begin{array}{c}-7.33 \\
(-15.19)\end{array}$ & $* * *$ & $\begin{array}{c}-5.582 \\
(-10.44)\end{array}$ & *** \\
\hline $\begin{array}{l}\text { Ind. \& year } \\
\text { dummies }\end{array}$ & Yes & & Yes & & Yes & & Yes & & Yes & & Yes & \\
\hline $\mathrm{N}$ & 9,771 & & 9,771 & & 9,771 & & 9,771 & & 9,587 & & 4,237 & \\
\hline R-squared & 0.16 & & 0.15 & & 0.15 & & 0.16 & & 0.15 & & 0.12 & \\
\hline
\end{tabular}


Table 3B

\section{Likelihood of a Secondary Deal: Robustness checks}

This table presents robustness checks of the logistic regression in which the dependent variable is an indicator variable with value 1 if the seller in a deal is a PE firm. Main variables are described as follows. Industry Specialization is a dummy variable that takes the value 1 if the PE fund family has done more than one-third of its past deals in the same industry group as the target's industry. Small (Medium) [Large] Size Specialization is an indicator variable equal to 1 if the PE fund family has done more than two-thirds of its deals in the small (medium) [large] size category, defined as deals with an imputed enterprise value lower than 50 million (between 50 and 250 million) [more than 250 million] real 2010 U.S. dollars. Industry Concentration is the Herfindahl index, by geography (U.S. vs. Europe) and year, of public firms with the 48 Fama-French industry code as the target firm. Asset Liquidity is the target industry's ratio of the value of corporate transactions (excluding LBOs) to the value of the total assets of public firms in that industry (Schlingemann, Stulz and Walkling, 2002). Past LBO Activity is the log of the moving average of LBO activity over the previous 5 years, measured in billions of real U.S. dollars. All other variables are defined as in Table 3. Regressions include industry dummies and yearly dummies. We use standard errors clustered by deal year to accommodate heteroskedasticity and within-year autocorrelation. T-statistics are reported in parentheses and $* * *, * * *$ denote significance at $1 \%, 5 \%$ and $10 \%$. 


\begin{tabular}{|c|c|c|c|c|c|c|c|c|c|c|c|c|}
\hline \multicolumn{13}{|c|}{ Dependent variable: Secondary Deal Indicator } \\
\hline & $(1)$ & & (2) & & (3) & & (4) & & (5) & & (6) & \\
\hline \multirow[t]{2}{*}{ Buy Pressure } & 0.261 & $* * *$ & 0.260 & $* * *$ & 0.259 & $* * *$ & 0.259 & $* * *$ & 0.247 & $* * *$ & 0.249 & $* * *$ \\
\hline & $(4.79)$ & & $(4.47)$ & & $(4.87)$ & & $(4.59)$ & & $(4.33)$ & & $(4.12)$ & \\
\hline \multirow[t]{2}{*}{ Industry Specialization } & -0.029 & & -0.010 & & & & & & & & & \\
\hline & $(-0.26)$ & & $(-0.09)$ & & & & & & & & & \\
\hline \multirow[t]{2}{*}{ Small Size Specialization } & & & & & 0.222 & & 0.227 & & & & & \\
\hline & & & & & $(0.90)$ & & $(0.95)$ & & & & & \\
\hline \multirow[t]{2}{*}{ Medium Size Specialization } & & & & & -0.048 & & -0.040 & & & & & \\
\hline & & & & & $(-0.68)$ & & $(-0.56)$ & & & & & \\
\hline \multirow[t]{2}{*}{ Large Size Specialization } & & & & & -0.093 & & -0.088 & & & & & \\
\hline & & & & & $(-0.91)$ & & $(-0.87)$ & & & & & \\
\hline \multirow[t]{2}{*}{ Industry Herfindahl Index } & & & & & & & & & 0.395 & & 0.426 & \\
\hline & & & & & & & & & $(0.84)$ & & $(0.90)$ & \\
\hline \multirow[t]{2}{*}{ Industry Asset Liquidity } & & & & & & & & & 0.959 & & 0.958 & \\
\hline & & & & & & & & & $(0.89)$ & & $(0.91)$ & \\
\hline \multirow[t]{2}{*}{ Past LBO Activity } & & & & & & & & & 0.811 & $* *$ & 0.776 & $* *$ \\
\hline & & & & & & & & & $(2.28)$ & & $(2.14)$ & \\
\hline \multirow[t]{2}{*}{ Imputed TEV } & 0.706 & $* * *$ & 0.708 & $* * *$ & 0.722 & $* * *$ & 0.723 & $* * *$ & 0.704 & $* * *$ & 0.706 & $* * *$ \\
\hline & $(20.75)$ & & $(18.60)$ & & $(16.27)$ & & $(15.50)$ & & (20.00) & & $(18.08)$ & \\
\hline \multirow[t]{2}{*}{ Mgmt. Participation } & 0.467 & $* * *$ & 0.451 & $* * *$ & 0.468 & $* * *$ & 0.451 & $* * *$ & 0.474 & $* * *$ & 0.458 & $* * *$ \\
\hline & $(6.23)$ & & $(5.98)$ & & $(6.11)$ & & $(5.84)$ & & $(6.41)$ & & $(6.15)$ & \\
\hline \multirow[t]{2}{*}{ U.S. Target } & -0.254 & $* * *$ & -0.221 & $* *$ & -0.249 & $* * *$ & -0.209 & $* *$ & -0.185 & $* *$ & -0.181 & * \\
\hline & $(-3.05)$ & & $(-2.40)$ & & $(-2.88)$ & & $(-2.26)$ & & $(-2.33)$ & & $(-1.87)$ & \\
\hline \multirow[t]{2}{*}{ Syndicated } & -0.132 & $*$ & -0.132 & $*$ & -0.135 & $*$ & -0.136 & $* *$ & -0.131 & $*$ & -0.130 & $*$ \\
\hline & $(-1.87)$ & & $(-1.94)$ & & $(-1.89)$ & & $(-1.97)$ & & $(-1.86)$ & & $(-1.89)$ & \\
\hline \multirow[t]{2}{*}{ Affiliated } & & & 0.136 & $* *$ & & & 0.139 & $* *$ & & & 0.133 & $* *$ \\
\hline & & & $(2.16)$ & & & & $(2.22)$ & & & & $(2.13)$ & \\
\hline \multirow[t]{2}{*}{ Novice } & & & 0.005 & & & & -0.006 & & & & 0.001 & \\
\hline & & & $(0.07)$ & & & & $(-0.09)$ & & & & $(0.02)$ & \\
\hline \multirow[t]{2}{*}{ HY Spread } & & & -0.028 & $*$ & & & -0.029 & $*$ & & & -0.036 & $* *$ \\
\hline & & & $(-1.68)$ & & & & $(-1.71)$ & & & & $(-2.30)$ & \\
\hline \multirow[t]{2}{*}{ Cold IPO Market } & & & -0.039 & & & & -0.045 & & & & 0.009 & \\
\hline & & & $(-0.32)$ & & & & $(-0.38)$ & & & & $(-0.07)$ & \\
\hline \multirow[t]{2}{*}{ Intercept } & -8.03 & $* * *$ & -7.33 & $* * *$ & -8.09 & $* * *$ & -7.38 & $* * *$ & -10.11 & $* * *$ & -9.49 & $* * *$ \\
\hline & $(-14.35)$ & & $(-15.05)$ & & $(-13.94)$ & & $(-14.93)$ & & $(-12.24)$ & & $(-10.05)$ & \\
\hline Industry \& year dummies & Yes & & Yes & & Yes & & Yes & & Yes & & Yes & \\
\hline $\mathrm{N}$ & 9,771 & & 9,587 & & 9,771 & & 9,587 & & 9,744 & & 9,576 & \\
\hline R-squared & 0.16 & & 0.15 & & 0.16 & & 0.15 & & 0.16 & & 0.16 & \\
\hline
\end{tabular}




\section{Table 4}

\section{Valuation of Secondary Deals}

This table presents regression results of the relation between the Excess Sales Multiple (Panel A) and Excess Ebitda Multiple (Panel B) and Buy Pressure for Secondary deals. Excess Sales (Ebitda) Mutiple is the difference between the target's Sales (Ebitda) Multiple and a valuation benchmark constructed as a follows. For every year, geography (U.S. versus Europe), industry (Fama-French 12-industry classification) and public status (public or private), we compute the median sales multiple for all merger transactions with value larger than 1 million dollars involving a majority stake over the previous two years relative to the date of the LBO. Columns (1) to (5) present results as interactions of Secondary deals and the variables of interest for the entire sample whereas Column (6) shows results within the sub-sample of Secondary deals. Secondary deals are deals in which the seller in a deal is a PE fund. Buy Pressure is the sum of variables Dry Powder, Late Buyer, and Lack of Reputation. Dry Powder is an indicator variable equal to 1 if the buyer is above median in terms of fund raising and below median in terms of deal activity. These criteria are computed as follows. First, for each PE fund family and year, we calculate the aggregate funds raised in the past 3 years, and the corresponding median across fund families in that year. Second, for each PE fund family and year, we compute the aggregate dollar value of all investment made during the past three years, and its respective median across fund families in that year. Late Buyer is an indicator variable with value 1 if equal to 1 if the buyer's most recent fund at the time of the deal is at the end of its investment period (4 to 6 years after inception). Lack of Reputation is an indicator variable equal to 1 if the buyer is not among the PEI Media Top 50 PE firms. Buyer Size is the log of the value of deals done by the buyer in the last five years. Mgmt. Participation is an indicator variable equal to 1 if at least one member of the management team of the target is referenced as an investor in the LBO transaction. U.S. target is equal to 1 if the target is headquartered in the US. Syndicated is an indicator variable equal to 1 , if there is more than one buyer. Fund belonging to the same fund family are counted as a single buyer. Affiliated is an indicator variable equal to 1 , if the buyer is affiliated to a financial institution or government agency. Novice is an indicator variable with value 1 if the buyer is a PE fund family with 3 funds or less under management at the time of the LBO deal. HY Spread is the difference, at the time of the LBO, between the Barclays High Yield Composite index and the Barclays average corporate AAA corporate bond rate. The index is only available after 1987. Cold IPO Market is an indicator variable equal to 1 if the IPO market is 'cold' at the time of the LBO. To define a cold [hot] IPO market, we compute the aggregate deal value of IPOs taking place in the same geography (U.S. or Europe), same Fama-French 12-code industry, and year as the target firm, and check if this value is lower [higher] than the geography- and industry-level time series mean. All monetary values are measured in real December 2010 U.S. dollars, after conversion at historical exchange, rates. Regressions include industry dummies and yearly dummies. Industries are defined using the Fama and French (1992) classification. We use standard errors clustered by deal year to accommodate heteroscekedasticity and within-year autocorrelation. T-statistics are reported in parentheses and the symbols $* * *, * *, *$ denote significance at $1 \%, 5 \%$ and $10 \%$. 


\begin{tabular}{|c|c|c|c|c|c|c|c|c|c|c|c|c|}
\hline \multicolumn{13}{|c|}{ Panel A. Dependent Variable: Excess Sales Multiple } \\
\hline & $(1)$ & & (2) & & (3) & & (4) & & $(5)$ & & (6) & \\
\hline Buy Pressure & $\begin{array}{l}-0.188 \\
(-5.43)\end{array}$ & $* * *$ & & & & & & & $\begin{array}{l}-0.192 \\
(-5.40)\end{array}$ & $* * *$ & & \\
\hline Secondary*Buy Pressure & $\begin{array}{l}0.218 \\
(2.57)\end{array}$ & ** & & & & & & & $\begin{array}{l}0.226 \\
(2.66)\end{array}$ & $* *$ & $\begin{array}{l}0.146 \\
(2.47)\end{array}$ & $* *$ \\
\hline Dry Powder & & & $\begin{array}{l}-0.032 \\
(-0.38)\end{array}$ & & & & & & & & & \\
\hline Secondary*Dry Powder & & & $\begin{array}{l}0.261 \\
(1.91)\end{array}$ & $*$ & & & & & & & & \\
\hline Late buyer & & & & & $\begin{array}{l}-0.163 \\
(-1.91)\end{array}$ & * & & & & & & \\
\hline Secondary*Late Buyer & & & & & $\begin{array}{l}0.281 \\
(1.74)\end{array}$ & * & & & & & & \\
\hline Lack of Reputation & & & & & & & $\begin{array}{l}-0.444 \\
(-6.12)\end{array}$ & $* * *$ & & & & \\
\hline Secondary*Lack of Reputation & & & & & & & $\begin{array}{l}0.121 \\
(0.82)\end{array}$ & & & & & \\
\hline Secondary & $\begin{array}{l}0.106 \\
(0.80)\end{array}$ & & $\begin{array}{c}0.28 \\
(3.13)\end{array}$ & $* * *$ & $\begin{array}{l}0.286 \\
(3.04)\end{array}$ & $* * *$ & $\begin{array}{l}(0.28) \\
(2.19)\end{array}$ & $* *$ & $\begin{array}{l}0.101 \\
(0.75)\end{array}$ & & & \\
\hline Buyer Size & $\begin{array}{l}0.058 \\
(3.72)\end{array}$ & $* * *$ & $\begin{array}{l}0.078 \\
(5.51)\end{array}$ & $* * *$ & $\begin{array}{l}0.077 \\
(5.39)\end{array}$ & $* * *$ & $\begin{array}{l}0.025 \\
(1.60)\end{array}$ & & $\begin{array}{l}0.066 \\
(3.88)\end{array}$ & $* * *$ & $\begin{array}{l}0.083 \\
(1.98)\end{array}$ & $*$ \\
\hline Mgmt. Participation & $\begin{array}{c}-0.07 \\
(-1.92)\end{array}$ & * & $\begin{array}{l}-0.082 \\
(-2.31)\end{array}$ & $* *$ & $\begin{array}{l}-0.087 \\
(-2.49)\end{array}$ & $* *$ & $\begin{array}{l}-0.038 \\
(-1.01)\end{array}$ & & $\begin{array}{l}-0.056 \\
(-1.51)\end{array}$ & & $\begin{array}{l}-0.015 \\
(-0.26)\end{array}$ & \\
\hline U.S. Target & $\begin{array}{l}-0.073 \\
(-1.25)\end{array}$ & & $\begin{array}{l}-0.069 \\
(-1.18)\end{array}$ & & $\begin{array}{l}-0.068 \\
(-1.16)\end{array}$ & & $\begin{array}{l}-0.084 \\
(-1.49)\end{array}$ & & $\begin{array}{l}-0.106 \\
(-1.20)\end{array}$ & & $\begin{array}{l}0.185 \\
(1.42)\end{array}$ & \\
\hline Syndicated & $\begin{array}{l}-0.006 \\
(-0.12)\end{array}$ & & $\begin{array}{l}-0.001 \\
(-0.02)\end{array}$ & & $\begin{array}{l}-0.007 \\
(-0.14)\end{array}$ & & $\begin{array}{l}-0.003 \\
(-0.06)\end{array}$ & & $\begin{array}{l}0.011 \\
(0.23)\end{array}$ & & $\begin{array}{l}-0.142 \\
(-2.81)\end{array}$ & $* *$ \\
\hline Affiliated & & & & & & & & & $\begin{array}{l}-0.098 \\
(-1.94)\end{array}$ & $*$ & & \\
\hline Novice & & & & & & & & & $\begin{array}{c}0.048 \\
(-0.57)\end{array}$ & & & \\
\hline HY Spread & & & & & & & & & $\begin{array}{l}-0.011 \\
(-0.69)\end{array}$ & & & \\
\hline Cold IPO Market & & & & & & & & & $\begin{array}{l}0.009 \\
(0.11)\end{array}$ & & & \\
\hline Intercept & $\begin{array}{l}0.921 \\
(5.11)\end{array}$ & $* * *$ & $\begin{array}{l}1.046 \\
(4.80)\end{array}$ & $* * *$ & $\begin{array}{l}1.007 \\
(4.19)\end{array}$ & $* * *$ & $\begin{array}{l}1.165 \\
(4.34)\end{array}$ & $* * *$ & $\begin{array}{l}-0.381 \\
(-1.09)\end{array}$ & & $\begin{array}{l}0.371 \\
(1.10)\end{array}$ & \\
\hline Industry \& year dummies & Yes & & Yes & & Yes & & Yes & & Yes & & Yes & \\
\hline $\mathrm{N}$ & 1399 & & 1399 & & 1399 & & 1399 & & 1383 & & 337 & \\
\hline R-squared & 0.10 & & 0.09 & & 0.09 & & 0.11 & & 0.10 & & 0.12 & \\
\hline
\end{tabular}


Table 4

Valuation of Secondary Deals (cont.)

\begin{tabular}{|c|c|c|c|c|c|c|c|c|c|c|c|c|}
\hline \multicolumn{13}{|c|}{ Panel B. Dependent Variable: Excess Ebitda Multiple } \\
\hline & (1) & & $(2)$ & & (3) & & (4) & & $(5)$ & & (6) & \\
\hline Buy Pressure & $\begin{array}{l}-0.584 \\
(-1.77)\end{array}$ & $*$ & & & & & & & $\begin{array}{l}-0.465 \\
(-1.23)\end{array}$ & & & \\
\hline Secondary*Buy Pressure & $\begin{array}{c}2.36 \\
(3.22)\end{array}$ & $* * *$ & & & & & & & $\begin{array}{l}2.309 \\
(3.18)\end{array}$ & $* * *$ & $\begin{array}{l}2.407 \\
(3.36)\end{array}$ & $* * *$ \\
\hline Dry Powder & & & $\begin{array}{l}-0.055 \\
(-0.12)\end{array}$ & & & & & & & & & \\
\hline Secondary*Dry Powder & & & $\begin{array}{c}2.848 \\
(-2.03)\end{array}$ & $* *$ & & & & & & & & \\
\hline Late buyer & & & & & $\begin{array}{l}-1.007 \\
(-1.83)\end{array}$ & $*$ & & & & & & \\
\hline Secondary*Late Buyer & & & & & $\begin{array}{c}2.274 \\
(-1.72)\end{array}$ & $*$ & & & & & & \\
\hline Lack of Reputation & & & & & & & $\begin{array}{l}-0.864 \\
(-1.88)\end{array}$ & $*$ & & & & \\
\hline Secondary*Lack of Reputation & & & & & & & $\begin{array}{c}1.203 \\
(-1.05)\end{array}$ & & & & & \\
\hline Secondary & $\begin{array}{l}-1.598 \\
(-1.28)\end{array}$ & & $\begin{array}{l}0.236 \\
(0.25)\end{array}$ & & $\begin{array}{c}0.493 \\
(0.68)\end{array}$ & & $\begin{array}{l}(0.38) \\
(0.41)\end{array}$ & & $\begin{array}{l}-1.468 \\
(-1.23)\end{array}$ & & & \\
\hline Buyer Size & $\begin{array}{l}0.027 \\
(0.19)\end{array}$ & & $\begin{array}{l}0.045 \\
(0.28)\end{array}$ & & $\begin{array}{l}0.051 \\
(0.33)\end{array}$ & & $\begin{array}{l}-0.037 \\
(-0.23)\end{array}$ & & $\begin{array}{l}0.129 \\
(1.41)\end{array}$ & & $\begin{array}{c}0.113 \\
(0.39)\end{array}$ & \\
\hline Mgmt. Participation & $\begin{array}{c}-0.63 \\
(-1.48)\end{array}$ & & $\begin{array}{l}-0.663 \\
(-1.57)\end{array}$ & & $\begin{array}{l}-0.710 \\
(-1.54)\end{array}$ & & $\begin{array}{l}-0.603 \\
(-1.44)\end{array}$ & & $\begin{array}{c}-0.56 \\
(-1.33)\end{array}$ & & $\begin{array}{l}0.121 \\
(0.10)\end{array}$ & \\
\hline U.S. Target & $\begin{array}{l}0.344 \\
(0.45)\end{array}$ & & $\begin{array}{l}0.400 \\
(0.52)\end{array}$ & & $\begin{array}{l}0.388 \\
(0.52)\end{array}$ & & $\begin{array}{l}0.375 \\
(0.49)\end{array}$ & & $\begin{array}{l}0.118 \\
(0.17)\end{array}$ & & $\begin{array}{l}-1.229 \\
(-0.69)\end{array}$ & \\
\hline Syndicated & $\begin{array}{l}-0.684 \\
(-1.98)\end{array}$ & $*$ & $\begin{array}{l}-0.689 \\
(-1.87)\end{array}$ & * & $\begin{array}{l}-0.700 \\
(-2.08)\end{array}$ & $*$ & $\begin{array}{l}-0.695 \\
(-1.92)\end{array}$ & $*$ & $\begin{array}{l}-0.444 \\
(-1.46)\end{array}$ & & $\begin{array}{l}-1.644 \\
(-1.10)\end{array}$ & \\
\hline Affiliated & & & & & & & & & $\begin{array}{l}-0.621 \\
(-0.89)\end{array}$ & & & \\
\hline Novice & & & & & & & & & $\begin{array}{c}0.307 \\
(-0.79)\end{array}$ & & & \\
\hline HY Spread & & & & & & & & & $\begin{array}{l}-0.069 \\
(-0.96)\end{array}$ & & & \\
\hline Cold IPO Market & & & & & & & & & $\begin{array}{l}0.087 \\
(0.12)\end{array}$ & & & \\
\hline Intercept & $\begin{array}{l}3.300 \\
(0.66)\end{array}$ & & $\begin{array}{l}-1.023 \\
(-0.31)\end{array}$ & & $\begin{array}{l}-1.523 \\
(-0.46)\end{array}$ & & $\begin{array}{l}2.259 \\
(0.47)\end{array}$ & & $\begin{array}{l}6.900 \\
(2.14)\end{array}$ & ** & $\begin{array}{l}-11.05 \\
(-3.90)\end{array}$ & $* * *$ \\
\hline Industry \& year dummies & Yes & & Yes & & Yes & & Yes & & Yes & & Yes & \\
\hline $\mathrm{N}$ & 684 & & 684 & & 684 & & 684 & & 674 & & 144 & \\
\hline R-squared & 0.07 & & 0.06 & & 0.06 & & 0.05 & & 0.06 & & 0.17 & \\
\hline
\end{tabular}




\section{Table 5}

\section{Likelihood of Secondary Exits}

This table presents results of a logistic regression, where the dependent variable is a Secondary Exit, an indicator variable with value 1 if the exit route of the LBO is a sale to another PE fund or group of PE funds. The explanatory variables are Sell Pressure, which is the sum of variables Late Seller, Late Exit, and Lack of Reputation. ). Late Seller is an indicator variable with value 1 , if the sale takes place in years 9 or 10 of the PE fund family's oldest active fund (i.e. less than 11 years old). Last Exit is equal to 1 if three or more years have elapsed since the PE fund family last exited an LBO deal. Lack of Reputation is an indicator variable equal to 1 if the buyer is not among the PEI Media Top 50 PE firms. Imputed TEV of the target firm is the sum of the target's equity market value valued at the LBO offer price, and the target's net debt (financial debt minus cash and marketable securities). For transactions without deal value information, we compute an estimate of deal value using the methodology of Stromberg (2008) (see Appendix for further details). Mgmt. Participation is an indicator variable equal to 1 if at least one member of the management team of the target is referenced as an investor in the LBO transaction. U.S. target is equal to 1 if the target is headquartered in the US. Syndicated is an indicator variable equal to 1, if there is more than one buyer. Fund belonging to the same fund family are counted as a single buyer. Stage is the number of years elapsed since fund raising for the youngest fund in the PE fund family whose investment period overlaps with the LBO deal date (that is. whose deal date falls within years 1 through 6 of the lifetime of the fund). Add-ons is equal to 1, if there were significant acquisitions during the time that the buyer held the target firm in its portfolio. We define acquisitions as significant if there are three or more acquisitions made by the target company during this period or if they represent a cumulative dollar value of $5 \%$ or more of the original LBO deal value. Secondary is an indicator variable equal to 1 if the seller is a PE fund. Divisional is an indicator variable equal to 1 if the seller is a corporate entity. Public-to-private is an indicator variable equal to 1 if the target firm is a publicly listed company. Financial seller is an indicator variable equal to 1 if the seller is a financial institution. Exit Affiliation is an indicator variable equal to 1, if the buyer is affiliated to a financial institution or government agency. Exit Novice is an indicator variable with value 1 if the buyer is a PE fund family with 3 funds or less under management at the time of exit. Exit HY Spread is the difference, at the time of the exit, between the Barclays High Yield Composite index and the Barclays average corporate AAA corporate bond rate. The index is only available after 1987. Exit Cold IPO Market is an indicator variable equal to 1 if the IPO market is 'cold' at the time of the exit. To define a cold [hot] IPO market, we compute the aggregate deal value of IPOs taking place in the same geography (U.S. or Europe), same Fama-French 12-code industry, and year as the target firm, and check if this value is lower [higher] than the geography- and industry-level time series mean. All monetary values are measured in real December 2010 U.S. dollars, after conversion at historical exchange, rates. Regressions include industry dummies and yearly dummies. Industries are defined using the Fama and French (1992) classification. We use standard errors clustered by deal year to accommodate heteroscekedasticity and within-year autocorrelation. T-statistics are reported in parentheses and the symbols ***, **,* denote significance at $1 \%, 5 \%$ and $10 \%$. 


\begin{tabular}{|c|c|c|c|c|c|c|c|c|c|c|c|c|}
\hline \multicolumn{13}{|c|}{ Dependent variable: Secondary Exit Indicator } \\
\hline & $(1)$ & & $(2)$ & & (3) & & $(4)$ & & $(5)$ & & $(6)$ & \\
\hline Sell Pressure & $\begin{array}{c}0.183 \\
(3.20)\end{array}$ & $* * *$ & & & & & & & $\begin{array}{l}0.196 \\
(3.51)\end{array}$ & $* * *$ & $\begin{array}{c}0.21 \\
(3.01)\end{array}$ & $* * *$ \\
\hline Late Seller & & & $\begin{array}{l}0.281 \\
(2.24)\end{array}$ & $* *$ & & & & & & & & \\
\hline Last Exit & & & & & $\begin{array}{l}0.176 \\
(1.99)\end{array}$ & $* *$ & & & & & & \\
\hline Lack of Reputation & & & & & & & $\begin{array}{c}0.168 \\
(1.89)\end{array}$ & * & & & & \\
\hline Imputed TEV & $\begin{array}{c}0.032 \\
(1.03)\end{array}$ & & $\begin{array}{l}0.011 \\
(0.38)\end{array}$ & & $\begin{array}{c}0.012 \\
(0.40)\end{array}$ & & $\begin{array}{l}0.026 \\
(0.75)\end{array}$ & & $\begin{array}{c}0.031 \\
(1.00)\end{array}$ & & $\begin{array}{l}0.026 \\
(0.63)\end{array}$ & \\
\hline Mgmt. Participation & $\begin{array}{l}0.007 \\
(0.10)\end{array}$ & & $\begin{array}{l}0.016 \\
(0.22)\end{array}$ & & $\begin{array}{l}0.011 \\
(0.15)\end{array}$ & & $\begin{array}{c}0.002 \\
(0.03)\end{array}$ & & $\begin{array}{c}0.024 \\
(0.33)\end{array}$ & & $\begin{array}{l}-0.054 \\
(-0.68)\end{array}$ & \\
\hline U.S. Target & $\begin{array}{l}-0.422 \\
(-5.55)\end{array}$ & $* * *$ & $\begin{array}{l}-0.373 \\
(-5.32)\end{array}$ & $* * *$ & $\begin{array}{l}-0.391 \\
(-5.39)\end{array}$ & $* * *$ & $\begin{array}{l}-0.400 \\
(-5.57)\end{array}$ & $* * *$ & $\begin{array}{l}-0.418 \\
(-4.73)\end{array}$ & $* * *$ & $\begin{array}{l}-0.503 \\
(-4.67)\end{array}$ & $* * *$ \\
\hline Syndicated & $\begin{array}{c}0.08 \\
(1.10)\end{array}$ & & $\begin{array}{c}0.085 \\
(1.19)\end{array}$ & & $\begin{array}{c}0.088 \\
(1.22)\end{array}$ & & $\begin{array}{c}0.081 \\
(1.09)\end{array}$ & & $\begin{array}{c}0.091 \\
(1.29)\end{array}$ & & $\begin{array}{l}0.045 \\
(0.45)\end{array}$ & \\
\hline Stage & $\begin{array}{l}-0.027 \\
(-0.78)\end{array}$ & & $\begin{array}{l}-0.026 \\
(-0.80)\end{array}$ & & $\begin{array}{l}-0.011 \\
(-0.32)\end{array}$ & & $\begin{array}{l}-0.014 \\
(-0.40)\end{array}$ & & $\begin{array}{c}-0.03 \\
(-0.82)\end{array}$ & & $\begin{array}{l}-0.007 \\
(-0.15)\end{array}$ & \\
\hline Add-On & $\begin{array}{c}0.102 \\
(1.17)\end{array}$ & & $\begin{array}{c}0.088 \\
(0.99)\end{array}$ & & $\begin{array}{c}0.103 \\
(1.11)\end{array}$ & & $\begin{array}{c}0.099 \\
(1.11)\end{array}$ & & $\begin{array}{l}(0.12) \\
(1.32)\end{array}$ & & $\begin{array}{l}0.108 \\
(0.95)\end{array}$ & \\
\hline Secondary & $\begin{array}{l}0.381 \\
(3.21)\end{array}$ & $* * *$ & $\begin{array}{l}0.383 \\
(3.19)\end{array}$ & $* * *$ & $\begin{array}{l}0.387 \\
(3.27)\end{array}$ & $* * *$ & $\begin{array}{l}0.378 \\
(3.17)\end{array}$ & $* * *$ & $\begin{array}{l}(0.33) \\
(2.76)\end{array}$ & $* * *$ & $\begin{array}{l}0.169 \\
(0.90)\end{array}$ & \\
\hline Divisional & $\begin{array}{l}-0.204 \\
(-2.81)\end{array}$ & $* * *$ & $\begin{array}{l}-0.224 \\
(-3.09)\end{array}$ & $* * *$ & $\begin{array}{c}-0.22 \\
(-3.08)\end{array}$ & $* * *$ & $\begin{array}{l}-0.212 \\
(-2.91)\end{array}$ & $* * *$ & $\begin{array}{l}(0.21) \\
(-3.18)\end{array}$ & $* * *$ & $\begin{array}{l}-0.137 \\
(-1.35)\end{array}$ & \\
\hline Public to private & $\begin{array}{l}-0.326 \\
(-1.53)\end{array}$ & & $\begin{array}{l}-0.332 \\
(-1.57)\end{array}$ & & $\begin{array}{l}-0.327 \\
(-1.50)\end{array}$ & & $\begin{array}{c}-0.33 \\
(-1.54)\end{array}$ & & $\begin{array}{l}(0.39) \\
(-1.96)\end{array}$ & $* *$ & $\begin{array}{l}-0.309 \\
(-1.25)\end{array}$ & \\
\hline Financial seller & $\begin{array}{l}-0.087 \\
(-0.61)\end{array}$ & & $\begin{array}{l}-0.086 \\
(-0.60)\end{array}$ & & $\begin{array}{l}-0.087 \\
(-0.61)\end{array}$ & & $\begin{array}{l}-0.087 \\
(-0.61)\end{array}$ & & $\begin{array}{l}(0.11) \\
(-0.87)\end{array}$ & & $\begin{array}{l}-0.434 \\
(-1.71)\end{array}$ & * \\
\hline Affiliation & & & & & & & & & $\begin{array}{l}-0.039 \\
(-0.39)\end{array}$ & & & \\
\hline Exit Novice & & & & & & & & & $\begin{array}{l}-0.129 \\
(-1.95)\end{array}$ & $*$ & & \\
\hline Exit HY Spread & & & & & & & & & $\begin{array}{c}-0.09 \\
(-4.97)\end{array}$ & $* * *$ & & \\
\hline Exit Cold IPO Market & & & & & & & & & $\begin{array}{l}0.065 \\
(0.60)\end{array}$ & & & \\
\hline Intercept & $\begin{array}{c}-1.93 \\
(-5.03)\end{array}$ & $* * *$ & $\begin{array}{l}-1.809 \\
(-4.89)\end{array}$ & $* * *$ & $\begin{array}{l}-1.786 \\
(-4.76)\end{array}$ & $* * *$ & $\begin{array}{l}-1.891 \\
(-4.74)\end{array}$ & $* * *$ & $\begin{array}{l}-1.491 \\
(-3.66)\end{array}$ & $* * *$ & $\begin{array}{l}-1.851 \\
(-4.55)\end{array}$ & $* * *$ \\
\hline Industry \& year dummies & Yes & & Yes & & Yes & & Yes & & Yes & & Yes & \\
\hline $\mathrm{N}$ & 4,328 & & 4,328 & & 4,328 & & 4,328 & & 4,143 & & 2,209 & \\
\hline R-squared & 0.06 & & 0.06 & & 0.06 & & 0.06 & & 0.06 & & 0.07 & \\
\hline
\end{tabular}




\section{Table 6}

\section{Valuation of Secondary Exits}

This table presents regression results of the relation between the Excess Sales Multiple (Panel A) and Excess Ebitda Multiple (Panel B) at exit and Sell Pressure. Excess Sales (Ebitda) Mutiple is the difference between the target's Sales (Ebitda) Multiple and a valuation benchmark constructed as a follows. For every year, geography (U.S. versus Europe), industry (Fama-French 12-industry classification) and public status (public or private), we compute the median sales multiple for all merger transactions with value larger than 1 million dollars involving a majority stake over the previous two years relative to the date of the LBO. Columns (1) to (5) present results as interactions of Secondary Exit and the variables of interest for the entire sample whereas Column (6) shows results within the sub-sample of Secondary Exits. Secondary Exit is the exit route of the LBO involving sale to another PE fund or group of PE funds. Sell Pressure is the sum of variables Late Seller, Late Exit, and Lack of Reputation. Late Seller is an indicator variable with value 1, if the sale takes place in years 9 or 10 of the PE fund family's oldest active fund (i.e. less than 11 years old). Last Exit is equal to 1 if three or more years have elapsed since the PE fund family last exited an LBO deal. Lack of Reputation is an indicator variable equal to 1 if the buyer is not among the PEI Media Top 50 PE firms. Buyer Size is the log of the value of deals done by the buyer in the last five years. Mgmt. Participation is an indicator variable equal to 1 if at least one member of the management team of the target is referenced as an investor in the LBO transaction. U.S. target is equal to 1 if the target is headquartered in the US. Syndicated is an indicator variable equal to 1 , if there is more than one buyer. Fund belonging to the same fund family are counted as a single buyer.Stage is the number of years elapsed since fund raising for the youngest fund in the PE fund family whose investment period overlaps with the LBO deal date (that is. whose deal date falls within years 1 through 6 of the lifetime of the fund). Add-ons is equal to 1, if there were significant acquisitions during the time that the buyer held the target firm in its portfolio. We define acquisitions as significant if there are three or more acquisitions made by the target company during this period or if they represent a cumulative dollar value of $5 \%$ or more of the original LBO deal value. Affiliated is an indicator variable equal to 1 , if the buyer is affiliated to a financial institution or government agency. Exit Novice is an indicator variable with value 1 if the buyer is a PE fund family with 3 funds or less under management at the time of exit. Exit HY Spread is the difference, at the time of the exit, between the Barclays High Yield Composite index and the Barclays average corporate AAA corporate bond rate. The index is only available after 1987. Exit Cold IPO Market is an indicator variable equal to 1 if the IPO market is 'cold' at the time of the exit. To define a cold [hot] IPO market, we compute the aggregate deal value of IPOs taking place in the same geography (U.S. or Europe), same Fama-French 12industry classification, and year as the target firm, and check if this value is lower [higher] than the geography- and industrylevel time series mean. All monetary values are measured in real December 2010 U.S. dollars, after conversion at historical exchange, rates. Regressions include industry dummies, yearly dummies and dummies for deal type. Industries are defined using the Fama and French (1992) classification. We use standard errors clustered by deal year to accommodate heteroscekedasticity and within-year autocorrelation. T-statistics are reported in parentheses and the symbols ***, **,* denote significance at $1 \%, 5 \%$ and $10 \%$. 


\begin{tabular}{|c|c|c|c|c|c|c|c|c|c|c|c|c|}
\hline \multicolumn{13}{|c|}{ Panel A. Dependent variable: Exit Excess Sales Multiple } \\
\hline & (1) & & (2) & & (3) & & (4) & & (5) & & (6) & \\
\hline \multirow{2}{*}{ Sell Pressure } & -0.098 & & & & & & & & -0.059 & & & \\
\hline & $(-1.22)$ & & & & & & & & $(-0.82)$ & & & \\
\hline \multirow[t]{2}{*}{ Secondary*Sell Pressure } & -0.222 & $*$ & & & & & & & -0.209 & & -0.282 & $* *$ \\
\hline & $(-1.69)$ & & & & & & & & $(-1.47)$ & & $(-1.99)$ & \\
\hline \multirow[t]{2}{*}{ Late seller } & & & -0.259 & ** & & & & & & & & \\
\hline & & & $(-2.37)$ & & & & & & & & & \\
\hline \multirow[t]{2}{*}{ Secondary*Late Seller } & & & -0.297 & $*$ & & & & & & & & \\
\hline & & & $(-1.86)$ & & & & & & & & & \\
\hline \multirow[t]{2}{*}{ Last Exit } & & & & & 0.038 & & & & & & & \\
\hline & & & & & $(-0.21)$ & & & & & & & \\
\hline \multirow[t]{2}{*}{ Secondary* Last Exit } & & & & & -0.14 & & & & & & & \\
\hline & & & & & $(-0.50)$ & & & & & & & \\
\hline \multirow[t]{2}{*}{ Lack of Reputation } & & & & & & & -0.085 & & & & & \\
\hline & & & & & & & $(-0.55)$ & & & & & \\
\hline \multirow{2}{*}{ Secondary*Lack of Reputation } & & & & & & & -0.128 & & & & & \\
\hline & & & & & & & $(-0.50)$ & & & & & \\
\hline \multirow[t]{2}{*}{ Secondary } & 0.347 & $* *$ & 0.185 & $*$ & 0.134 & & $(0.22)$ & & 0.316 & $* *$ & & \\
\hline & $(2.40)$ & & (1.69) & & $(1.45)$ & & $(1.16)$ & & $(2.25)$ & & & \\
\hline \multirow[t]{2}{*}{ Buyer Size } & 0.041 & $* *$ & 0.054 & $* * *$ & 0.056 & $* * *$ & 0.046 & $* *$ & 0.042 & $* *$ & 0.053 & \\
\hline & $(2.20)$ & & $(3.81)$ & & $(3.77)$ & & $(2.35)$ & & $(2.21)$ & & $(1.11)$ & \\
\hline \multirow[t]{2}{*}{ Mgmt. Participation } & -0.133 & $*$ & -0.158 & $* *$ & -0.154 & $* *$ & -0.141 & $*$ & -0.131 & $*$ & -0.102 & \\
\hline & $(-1.82)$ & & $(-2.21)$ & & $(-2.17)$ & & $(-1.96)$ & & $(-1.80)$ & & $(-0.47)$ & \\
\hline \multirow[t]{2}{*}{ U.S. Target } & 0.169 & $*$ & 0.144 & $*$ & 0.151 & $*$ & 0.16 & $*$ & 0.218 & & -0.154 & \\
\hline & (1.92) & & (1.73) & & $(1.75)$ & & (1.87) & & (1.65) & & $(-0.89)$ & \\
\hline \multirow[t]{2}{*}{ Syndicated } & -0.086 & & -0.074 & & -0.081 & & -0.085 & & -0.089 & & 0.108 & \\
\hline & $(-0.88)$ & & $(-0.78)$ & & $(-0.83)$ & & $(-0.88)$ & & $(-0.92)$ & & -0.62 & \\
\hline \multirow[t]{2}{*}{ Stage } & 0.031 & & 0.04 & & 0.015 & & 0.019 & & 0.024 & & $(-0.03)$ & \\
\hline & $(1.05)$ & & $(1.39)$ & & $(0.52)$ & & $(0.67)$ & & $(-0.80)$ & & $(-0.50)$ & \\
\hline \multirow[t]{2}{*}{ Add-On } & 0.121 & & 0.146 & & 0.12 & & 0.115 & & 0.128 & & 0.420 & \\
\hline & $(1.06)$ & & $(1.30)$ & & $(1.05)$ & & $(1.02)$ & & $(-1.08)$ & & $(1.54)$ & \\
\hline \multirow[t]{2}{*}{ Affilated } & & & & & & & & & -0.13 & & & \\
\hline & & & & & & & & & $(-1.21)$ & & & \\
\hline \multirow[t]{2}{*}{ Novice } & & & & & & & & & -0.102 & & & \\
\hline & & & & & & & & & $(-1.49)$ & & & \\
\hline \multirow[t]{2}{*}{ HY Spread } & & & & & & & & & -0.049 & $*$ & & \\
\hline & & & & & & & & & $(-1.86)$ & & & \\
\hline \multirow[t]{2}{*}{ Cold IPO Market } & & & & & & & & & -0.151 & & & \\
\hline & & & & & & & & & $(-1.06)$ & & & \\
\hline Intercept & 0.05 & & -0.119 & & -0.093 & & -0.272 & & 0.054 & & 3.553 & \\
\hline & $(0.13)$ & & $(-0.49)$ & & $(-0.26)$ & & $(-1.51)$ & & $(-0.24)$ & & $(2.56)$ & \\
\hline Industry \& year dummies & Yes & & Yes & & Yes & & Yes & & Yes & & Yes & \\
\hline LBO type dummies & Yes & & Yes & & Yes & & Yes & & Yes & & Yes & \\
\hline $\mathrm{N}$ & 1127 & & 1127 & & 1127 & & 1127 & & 1098 & & 237 & \\
\hline R-squared & 0.05 & & 0.05 & & 0.05 & & 0.05 & & 0.06 & & 0.10 & \\
\hline
\end{tabular}




\begin{tabular}{|c|c|c|c|c|c|c|c|c|c|c|c|}
\hline \multicolumn{12}{|c|}{ Panel B. Dependent variable: Exit Excess Ebitda Multiple } \\
\hline & (1) & & (2) & & (3) & & (4) & & (5) & & (6) \\
\hline \multirow[t]{2}{*}{ Sell Pressure } & 0.28 & & & & & & & & 0.634 & $* *$ & \\
\hline & $(-1.18)$ & & & & & & & & $(-2.61)$ & & \\
\hline \multirow[t]{2}{*}{ Secondary*Sell Pressure } & -0.366 & & & & & & & & -0.414 & & -1.241 \\
\hline & $(-0.29)$ & & & & & & & & $(-0.32)$ & & $(-1.15)$ \\
\hline \multirow[t]{2}{*}{ Late seller } & & & 0.496 & & & & & & & & \\
\hline & & & $(-0.70)$ & & & & & & & & \\
\hline \multirow[t]{2}{*}{ Secondary*Late Seller } & & & -2.883 & * & & & & & & & \\
\hline & & & $(-1.74)$ & & & & & & & & \\
\hline \multirow[t]{2}{*}{ Last Exit } & & & & & 1.774 & $* *$ & & & & & \\
\hline & & & & & $(-2.11)$ & & & & & & \\
\hline \multirow{2}{*}{ Secondary*Last Exit } & & & & & -2.852 & $* *$ & & & & & \\
\hline & & & & & $(-2.08)$ & & & & & & \\
\hline \multirow[t]{2}{*}{ Lack of Reputation } & & & & & & & -0.377 & & & & \\
\hline & & & & & & & $(-0.72)$ & & & & \\
\hline \multirow[t]{2}{*}{ Secondary*Lack of Reputation } & & & & & & & 2.319 & & & & \\
\hline & & & & & & & $(-1.56)$ & & & & \\
\hline \multirow[t]{2}{*}{ Secondary } & -0.831 & & -0.464 & & -0.895 & & $(-2.50)$ & $*$ & -0.912 & & \\
\hline & $(-0.47)$ & & $(-0.43)$ & & $(-0.92)$ & & $(-1.74)$ & & $(-0.52)$ & & \\
\hline \multirow[t]{2}{*}{ Buyer Size } & 0.05 & & 0.031 & & 0.048 & & 0.008 & & -0.014 & & -0.993 \\
\hline & $(0.48)$ & & $(0.30)$ & & $(0.48)$ & & $(0.07)$ & & $(-0.12)$ & & $(-0.99)$ \\
\hline \multirow[t]{2}{*}{ Mgmt. Participation } & -0.155 & & -0.099 & & -0.226 & & -0.215 & & -0.07 & & 0.018 \\
\hline & $(-0.26)$ & & $(-0.16)$ & & $(-0.39)$ & & $(-0.36)$ & & $(-0.12)$ & & $(-0.01)$ \\
\hline \multirow[t]{2}{*}{ U.S. Target } & 1.369 & $* *$ & 1.454 & $* * *$ & 1.302 & $* *$ & 1.357 & $* *$ & 1.991 & $* * *$ & 0.696 \\
\hline & $(2.58)$ & & $(2.85)$ & & $(2.46)$ & & $(2.55)$ & & $(3.36)$ & & $(-0.24)$ \\
\hline \multirow[t]{2}{*}{ Syndicated } & -0.493 & & -0.49 & & -0.449 & & -0.536 & & -0.343 & & $3.005 *$ \\
\hline & $(-0.80)$ & & $(-0.79)$ & & $(-0.74)$ & & $(-0.86)$ & & $(-0.56)$ & & $(-2.10)$ \\
\hline \multirow[t]{2}{*}{ Stage } & -0.066 & & -0.043 & & -0.036 & & -0.006 & & -0.07 & & 0.733 \\
\hline & $(-0.47)$ & & $(-0.28)$ & & $(-0.27)$ & & $(-0.04)$ & & $(-0.51)$ & & $(1.08)$ \\
\hline \multirow[t]{2}{*}{ Add-On } & 0.464 & & 0.489 & & 0.576 & & 0.517 & & 0.443 & & -1.019 \\
\hline & $(0.55)$ & & $(0.59)$ & & $(0.68)$ & & $(0.64)$ & & $(-0.51)$ & & $(-0.46)$ \\
\hline \multirow[t]{2}{*}{ Affilated } & & & & & & & & & -0.469 & & \\
\hline & & & & & & & & & $(-0.72)$ & & \\
\hline \multirow[t]{2}{*}{ Novice } & & & & & & & & & -1.449 & $* *$ & \\
\hline & & & & & & & & & $(-2.27)$ & & \\
\hline \multirow[t]{2}{*}{ HY Spread } & & & & & & & & & -0.206 & $*$ & \\
\hline & & & & & & & & & $(-1.95)$ & & \\
\hline \multirow[t]{2}{*}{ Cold IPO Market } & & & & & & & & & -1.396 & $*$ & \\
\hline & & & & & & & & & $(-2.01)$ & & \\
\hline Intercept & -6.425 & $* * *$ & -7.278 & $* * *$ & -0.779 & & -0.897 & & -3.05 & & -7.01 \\
\hline & $(-3.04)$ & & $(-4.48)$ & & $(-0.40)$ & & $(-0.45)$ & & $(-1.35)$ & & $(-0.63)$ \\
\hline Industry \& year dummies & Yes & & Yes & & Yes & & Yes & & Yes & & Yes \\
\hline LBO Deal type dummies & Yes & & Yes & & Yes & & Yes & & Yes & & Yes \\
\hline $\mathrm{N}$ & 613 & & 613 & & 613 & & 613 & & 599 & & 85 \\
\hline R-squared & 0.02 & & 0.02 & & 0.02 & & 0.02 & & 0.04 & & 0.1 \\
\hline
\end{tabular}


Table 7

\section{Valuation of Secondary Deals: Buyer and Seller Pressure}

This table presents regression results of the relation between the Excess Sales Multiple (Panel A) and Excess Ebitda Multiple (Panel B) for both Buy and Sell Pressure. Excess Sales (Ebitda) Mutiple is the difference between the target's Sales (Ebitda) Multiple and a valuation benchmark constructed as a follows. For every year, geography (U.S. versus Europe), industry (Fama-French 12-industry classification) and public status (public or private), we compute the median sales multiple for all merger transactions with value larger than 1 million dollars involving a majority stake over the previous two years relative to the date of the LBO. Secondary deals are deals in which the seller in a deal is a PE fund. Buy Pressure is the sum of variables Dry Powder, Late Buyer, and Lack of Reputation. Sell Pressure is the sum of variables Late Seller, Late Exit, and Lack of Reputation. Late Seller is an indicator variable with value 1, if the sale takes place in years 9 or 10 of the PE fund family's oldest active fund (i.e. less than 11 years old). Last Exit is equal to 1 if three or more years have elapsed since the PE fund family last exited an LBO deal. Lack of Reputation is an indicator variable equal to 1 if the buyer is not among the PEI Media Top 50 PE firms. Buyer Size is the log of the value of deals done by the buyer in the last five years. Mgmt. Participation is an indicator variable equal to 1 if at least one member of the management team of the target is referenced as an investor in the LBO transaction. U.S. target is equal to 1 if the target is headquartered in the US. Syndicated is an indicator variable equal to 1 , if there is more than one buyer. Fund belonging to the same fund family are counted as a single buyer. Affiliated is an indicator variable equal to 1 , if the buyer is affiliated to a financial institution or government agency. Novice is an indicator variable with value 1 if the buyer is a PE fund family with 3 funds or less under management at the time of the LBO deal. HY Spread is the difference, at the time of the LBO deal, between the Barclays High Yield Composite index and the Barclays average corporate AAA corporate bond rate. The index is only available after 1987. Cold IPO Market is an indicator variable equal to 1 if the IPO market is 'cold' at the time of the LBO deal. To define a cold [hot] IPO market, we compute the aggregate deal value of IPOs taking place in the same geography (U.S. or Europe), same Fama-French 12code industry, and year as the target firm, and check if this value is lower [higher] than the geography- and industry-level time series mean. All monetary values are measured in real December 2010 U.S. dollars, after conversion at historical exchange, rates. Regressions include industry dummies and yearly dummies. Industries are defined using the Fama and French (1992) classification. We use standard errors clustered by deal year to accommodate heteroscekedasticity and withinyear autocorrelation. T-statistics are reported in parentheses and the symbols $* * *, * *, *$ denote significance at $1 \%, 5 \%$ and $10 \%$. 


\begin{tabular}{|c|c|c|c|c|c|c|c|c|c|}
\hline \multicolumn{10}{|c|}{ Panel A. Dependent variable: Excess Sales Multiple } \\
\hline & (1) & $(2)$ & & (3) & & (4) & & $(5)$ & \\
\hline Buy Pressure & $\begin{array}{l}0.106 \\
(1.94)\end{array}$ & $\begin{array}{r}* \quad 0.109 \\
\\
(1.87)\end{array}$ & $*$ & $\begin{array}{l}0.123 \\
(2.19)\end{array}$ & $* *$ & $\begin{array}{l}0.122 \\
(2.30)\end{array}$ & $* *$ & $\begin{array}{l}0.130 \\
(1.66)\end{array}$ & $*$ \\
\hline Sell Pressure & $\begin{array}{l}-0.203 \\
(-1.80)\end{array}$ & * & & & & & & $\begin{array}{l}-0.164 \\
(-1.31)\end{array}$ & \\
\hline Late Seller & & $\begin{array}{l}-0.447 \\
(-4.22)\end{array}$ & $* * *$ & & & & & & \\
\hline Last Exit & & & & $\begin{array}{l}0.034 \\
(0.13)\end{array}$ & & & & & \\
\hline Lack of Reputation (Seller) & & & & & & $\begin{array}{l}-0.173 \\
(-0.97)\end{array}$ & & & \\
\hline Buyer Size & $\begin{array}{l}0.074 \\
-1.81\end{array}$ & $\begin{array}{rr}* & 0.086 \\
& -1.89\end{array}$ & $*$ & $\begin{array}{l}0.086 \\
-1.96\end{array}$ & $*$ & $\begin{array}{l}0.079 \\
-1.92\end{array}$ & $*$ & $\begin{array}{l}0.113 \\
(2.34)\end{array}$ & $* *$ \\
\hline Mgmt. Participation & $\begin{array}{c}-0.04 \\
(-0.43)\end{array}$ & $\begin{array}{l}-0.077 \\
(-0.74)\end{array}$ & & $\begin{array}{l}-0.069 \\
(-0.78)\end{array}$ & & $\begin{array}{l}-0.040 \\
(-0.42)\end{array}$ & & $\begin{array}{l}-0.013 \\
(-0.14)\end{array}$ & \\
\hline U.S. Target & $\begin{array}{c}0.158 \\
(-0.80)\end{array}$ & $\begin{array}{c}0.118 \\
(-0.60)\end{array}$ & & $\begin{array}{c}0.117 \\
(-0.61)\end{array}$ & & $\begin{array}{l}0.136 \\
(0.67)\end{array}$ & & $\begin{array}{l}-0.136 \\
(-0.54)\end{array}$ & \\
\hline Syndicated & $\begin{array}{l}-0.111 \\
(-1.69)\end{array}$ & $\begin{array}{l}-0.103 \\
(-1.65)\end{array}$ & & $\begin{array}{l}-0.143 \\
(-2.01)\end{array}$ & $*$ & $\begin{array}{l}-0.143 \\
(-1.96)\end{array}$ & * & $\begin{array}{l}-0.104 \\
(-1.40)\end{array}$ & \\
\hline Affiliated & & & & & & & & $\begin{array}{l}-0.084 \\
(-0.53)\end{array}$ & \\
\hline Novice & & & & & & & & $\begin{array}{l}0.267 \\
(1.38)\end{array}$ & \\
\hline HY Spread & & & & & & & & $\begin{array}{l}-0.082 \\
(-1.17)\end{array}$ & \\
\hline Cold IPO Market & & & & & & & & $\begin{array}{c}0.453 \\
(-2.35)\end{array}$ & $* *$ \\
\hline Intercept & $\begin{array}{l}2.079 \\
(1.80)\end{array}$ & $\begin{array}{r}* \quad 2.022 \\
\\
(1.86)\end{array}$ & $*$ & $\begin{array}{l}1.438 \\
(1.18)\end{array}$ & & $\begin{array}{l}1.602 \\
(1.44)\end{array}$ & & $\begin{array}{l}1.822 \\
(-1.74)\end{array}$ & $*$ \\
\hline Industry \& year dummies & Yes & Yes & & Yes & & Yes & & Yes & \\
\hline $\mathrm{N}$ & 296 & 296 & & 296 & & 296 & & 294 & \\
\hline R-squared & 0.08 & 0.08 & & 0.06 & & 0.07 & & 0.08 & \\
\hline
\end{tabular}


Table 7

Valuation of Secondary Deals: Buyer and Seller Pressure (cont.)

\begin{tabular}{|c|c|c|c|c|c|c|c|c|c|c|}
\hline \multicolumn{11}{|c|}{ Panel B. Dependent variable: Excess Ebitda Multiple } \\
\hline & (1) & & (2) & & (3) & & (4) & & (5) & \\
\hline \multirow[t]{2}{*}{ Buy Pressure } & 2.345 & $* *$ & 2.11 & $* *$ & 2.312 & $* *$ & 2.248 & $* *$ & 2.330 & * \\
\hline & $(2.46)$ & & $(2.16)$ & & $(2.45)$ & & $(2.81)$ & & $(2.42)$ & \\
\hline \multirow[t]{2}{*}{ Sell Pressure } & 0.499 & & & & & & & & 0.433 & \\
\hline & $(0.38)$ & & & & & & & & $(0.32)$ & \\
\hline \multirow[t]{2}{*}{ Late Seller } & & & -1.575 & & & & & & & \\
\hline & & & $(-0.84)$ & & & & & & & \\
\hline \multirow[t]{2}{*}{ Last Exit } & & & & & 1.008 & & & & & \\
\hline & & & & & $(0.41)$ & & & & & \\
\hline \multirow[t]{2}{*}{ Lack of Reputation (Seller) } & & & & & & & 1.441 & & & \\
\hline & & & & & & & $(0.96)$ & & & \\
\hline \multirow[t]{2}{*}{ Buyer Size } & -0.16 & & -0.183 & & -0.191 & & -0.113 & & -0.194 & \\
\hline & $(-0.47)$ & & $(-0.54)$ & & $(-0.51)$ & & $(-0.32)$ & & $(-0.62)$ & \\
\hline \multirow[t]{2}{*}{ Mgmt. Participation } & -0.72 & & -0.89 & & -0.678 & & -0.92 & & -0.671 & \\
\hline & $(-0.58)$ & & $(-0.76)$ & & $(-0.57)$ & & $(-0.72)$ & & $(-0.49)$ & \\
\hline \multirow[t]{2}{*}{ U.S. Target } & -2.575 & & -2.372 & & -2.56 & & -2.654 & & -2.039 & \\
\hline & $(-1.17)$ & & $(-1.27)$ & & $(-1.20)$ & & $(-1.35)$ & & $(-0.87)$ & \\
\hline \multirow[t]{2}{*}{ Syndicated } & -0.404 & & -0.179 & & -0.394 & & -0.216 & & -0.427 & \\
\hline & $(-0.27)$ & & $(-0.13)$ & & $(-0.26)$ & & $(-0.15)$ & & $(-0.23)$ & \\
\hline \multirow[t]{2}{*}{ Affiliated } & & & & & & & & & -0.717 & \\
\hline & & & & & & & & & $(-0.45)$ & \\
\hline \multirow[t]{2}{*}{ Novice } & & & & & & & & & -0.009 & \\
\hline & & & & & & & & & $(-0.01)$ & \\
\hline \multirow[t]{2}{*}{ HY Spread } & & & & & & & & & 0.137 & \\
\hline & & & & & & & & & $(0.20)$ & \\
\hline \multirow[t]{2}{*}{ Cold IPO Market } & & & & & & & & & -1.146 & \\
\hline & & & & & & & & & $(-0.38)$ & \\
\hline \multirow[t]{2}{*}{ Intercept } & 2.044 & & 3.898 & & 2.362 & & 1.593 & & 2.915 & \\
\hline & $(0.41)$ & & $(0.85)$ & & $(0.49)$ & & $(0.28)$ & & $(0.35)$ & \\
\hline Industry \& year dummies & Yes & & Yes & & Yes & & Yes & & Yes & \\
\hline $\mathrm{N}$ & 121 & & 121 & & 121 & & 121 & & 121 & \\
\hline R-squared & 0.26 & & 0.26 & & 0.26 & & 0.26 & & 0.23 & \\
\hline
\end{tabular}




\section{Table 8}

\section{Pressure and Leverage of Secondary Deals}

This table presents regression results of the relation between leverage and Buy Pressure. The dependent variable is Deal Leverage, the ratio of Senior Debt to Entreprise Value. Columns (1) to (2) show results for all sample deals using the interaction of Secondary and Buy Pressure whereas Columns (3) and (4) shows results within the sub-sample of Secondary deals. Past LBO Activity is the log of the moving average of LBO activity over the previous 5 years, measured in billions of real U.S. dollars. All other variables are defined as in Table 4. Regressions include industry dummies and yearly dummies. We use standard errors clustered by deal year to accommodate heteroscekedasticity and within-year autocorrelation. T-statistics are reported in parentheses and the symbols $* * *, * *, *$ denote significance at $1 \%, 5 \%$ and $10 \%$.

\begin{tabular}{|c|c|c|c|c|c|c|c|c|}
\hline & \multicolumn{8}{|c|}{ Dependent Variable: Debt to Enterprise Value } \\
\hline & \multicolumn{4}{|c|}{ All deals } & \multicolumn{4}{|c|}{ Secondary deals only } \\
\hline & (1) & & (2) & & (3) & & (4) & \\
\hline \multirow[t]{2}{*}{ Buy Pressure } & -0.100 & & -0.124 & * & -0.155 & & -0.186 & $* *$ \\
\hline & $(-1.42)$ & & $(-1.72)$ & & $(-1.60)$ & & $(-1.84)$ & \\
\hline \multirow[t]{2}{*}{ Secondary*Buy Pressure } & 0.028 & & 0.026 & & & & & \\
\hline & $(0.33)$ & & $(0.31)$ & & & & & \\
\hline \multirow[t]{2}{*}{ Secondary } & -0.115 & & -0.134 & & & & & \\
\hline & $(-0.87)$ & & $(-1.04)$ & & & & & \\
\hline \multirow[t]{2}{*}{ Imputed TEV } & -0.172 & $* * *$ & -0.182 & $* * *$ & -0.406 & $* *$ & -0.399 & $* *$ \\
\hline & $(-4.33)$ & & $(-4.47)$ & & $(-2.39)$ & & $(-2.38)$ & \\
\hline \multirow[t]{2}{*}{ Mgmt. Participation } & -0.103 & & -0.093 & & -0.333 & $*$ & -0.329 & * \\
\hline & $(-1.53)$ & & $(-1.41)$ & & $(-1.86)$ & & $(-1.83)$ & \\
\hline \multirow[t]{2}{*}{ U.S. Target } & -0.580 & $* * *$ & -0.499 & $* * *$ & -0.719 & $* *$ & -0.573 & $* * *$ \\
\hline & $(-3.47)$ & & $(-4.26)$ & & $(-2.50)$ & & $(-3.12)$ & \\
\hline \multirow[t]{2}{*}{ Syndicated } & -0.064 & & -0.068 & & 0.009 & & -0.006 & \\
\hline & $(-1.12)$ & & $(-1.27)$ & & $(0.11)$ & & $(-0.06)$ & \\
\hline \multirow[t]{2}{*}{ HY Spread } & -0.036 & $* *$ & -0.066 & $* * *$ & -0.044 & & -0.036 & \\
\hline & $(-2.32)$ & & $(-2.85)$ & & $(-0.45)$ & & $(-0.52)$ & \\
\hline \multirow[t]{2}{*}{ Affiliated } & & & 0.047 & & & & 0.010 & \\
\hline & & & $(0.74)$ & & & & $(0.09)$ & \\
\hline \multirow[t]{2}{*}{ Novice } & & & -0.043 & & & & -0.032 & \\
\hline & & & $(-0.74)$ & & & & $(-0.26)$ & \\
\hline \multirow[t]{2}{*}{ Past LBO Activity } & & & 1.736 & $* * *$ & & & 2.001 & $*$ \\
\hline & & & $(3.72)$ & & & & $(1.84)$ & \\
\hline \multirow[t]{2}{*}{ Intercept } & 2.428 & $* * *$ & -6.162 & $* *$ & 3.221 & $* *$ & -7.800 & \\
\hline & $(4.25)$ & & $(-2.25)$ & & $(2.50)$ & & $(-1.40)$ & \\
\hline Industry \& year dummies & Yes & & Yes & & Yes & & Yes & \\
\hline $\mathrm{N}$ & 700 & & 700 & & 196 & & 196 & \\
\hline R-squared & 0.20 & & 0.22 & & 0.25 & & 0.26 & \\
\hline
\end{tabular}




\section{Appendix A}

This appendix describes in detail the construction of the LBO sample. We extract from S\&P's Capital IQ all closed merger transactions featuring the keywords "Going Private Transaction", "Leveraged Buy Out (LBO)", "Management Buyout" and "Secondary LBO" transactions with targets located in the U.S. and in 12 European countries (Belgium, Denmark, Finland, France, Germany, Italy, Luxembourg, Netherlands, Spain, Sweden, Switzerland, and United Kingdom) for the period from January 1st, 1980 to December 31st, 2010. We exclude targets in financial industries, acquisitions of remaining interest, acquisitions of minority stakes, targets with reported negative sales or negative enterprise value, Venture Capital deals misidentified as LBOs in Capital IQ; corporate acquisitions in which the acquirer is not associated with a PE owner; acquisitions by non-PE investors, such as hedge funds, groups of individual investors, corporate venture funds, and non-PE arms of financial institutions. This initial sample includes 23,032 deals. After conducting extensive individual checks using the textual deal commentary, we further exclude: deals without information on the identity of buyers and sellers, acquisitions by management teams (e.g. management buy-outs) with no evidence of involvement by a PE sponsor; and deals in which the target firm is bankrupt or in financial distress. When an acquisition involves multiple stages or transactions, we keep the one in which the buyer acquired most of its stake (typically the first transaction).

Although Capital IQ contains the unique identifier(s) of the PE buyer(s), this information is sometimes available at the fund level (e.g. "KKR EUROPEAN BUYOUT FUND II, L.P.") and sometimes at the fund family level (e.g. "KOHLBERG KRAVIS ROBERTS \& CO.”). Moreover, we found cases in Capital IQ of families that are considered distinct but actually belong to the same PE group (e.g. "BARCLAYS PRIVATE EQUITY LTD." and "BARCLAYS PRIVATE EQUITY FRANCE SAS"). We therefore create a unique PE fund family identifier to address such cases.

For each deal we identify a "leading buyer": In single-buyer deals the leading buyer is the family of the acquiring fund; in syndicated deals the leading buyer is the PE fund family with highest reputation among all buyers, where reputation is measured as the dollar market share of the PE fund family across all LBOs conducted up to that year. For each deal and each leading buyer, we require that the acquisition date is within the investment period range (years 1 through 6 ) of at least one of the funds in the PE fund family. The final sample contains 9,771 LBO deals, out of which we able to trace 4,328 exit routes and dates. 


\section{Appendix B}

\begin{tabular}{|c|c|}
\hline \multicolumn{2}{|l|}{ Deal Variables } \\
\hline Variable: & Definition: \\
\hline Secondary & Indicator variable equal to 1 if the seller is a PE fund, and zero otherwise. \\
\hline Divisional & Indicator variable equal to 1 if the seller is a corporate entity, and zero otherwise. \\
\hline Financial seller & Indicator variable equal to 1 if the seller is a financial institution, and zero otherwise. \\
\hline Public to private & Indicator variable equal to 1 if the target firm is a publicly listed company, and zero otherwise. \\
\hline Private to private & $\begin{array}{l}\text { Indicator variable equal to } 1 \text { if the seller is a non-PE investor group or individual, and zero } \\
\text { otherwise. }\end{array}$ \\
\hline Imputed TEV & $\begin{array}{l}\text { Implied Total Enterprise Value (TEV) of the target firm is the sum of the target's equity market } \\
\text { value valued at the LBO offer price, and the target's net debt (financial debt minus cash and } \\
\text { marketable securities). For transactions without deal value information, we compute an estimate } \\
\text { of deal value using the methodology of Stromberg ( } 2008 \text { ). For all } 29,000 \text { deals in the initial } \\
\text { sample, we run a Heckman model of the likelihood of a deal having its value disclosed in the } \\
\text { first stage, and the TEV of the target in the second stage (see Table A-1 for details of this } \\
\text { procedure). TEV amounts are measured in real December } 2010 \text { U.S. dollars, after conversion at } \\
\text { historical exchange rates. }\end{array}$ \\
\hline Mgmt. Participation & $\begin{array}{l}\text { Indicator variable equal to } 1 \text { if at least one member of the management team of the target is } \\
\text { referenced as an investor in the LBO transaction, and zero otherwise. }\end{array}$ \\
\hline U.S. Target & Indicator variable equal to 1 if the target is headquartered in the U.S., and zero otherwise. \\
\hline Syndicated & $\begin{array}{l}\text { Indicator variable equal to } 1 \text { if there is more than one buyer, and zero otherwise. Fund belonging } \\
\text { to the same fund family are counted as a single buyer. }\end{array}$ \\
\hline Stage & $\begin{array}{l}\text { Number of years elapsed since fund raising for the youngest fund in the PE fund family whose } \\
\text { investment period overlaps with the LBO deal date (that is. whose deal date falls within years } 1 \\
\text { through } 6 \text { of the lifetime of the fund). }\end{array}$ \\
\hline HY Spread & $\begin{array}{l}\text { Difference, at the time of the LBO, between the Barclays High Yield Composite index and the } \\
\text { Barclays average corporate AAA corporate bond rate. The index is only available after } 1987 .\end{array}$ \\
\hline Cold IPO Market & $\begin{array}{l}\text { Indicator variable equal to } 1 \text { if the IPO market is 'cold' at the time of the LBO, and zero } \\
\text { otherwise. To define a cold [hot] IPO market, we compute the aggregate deal value of IPOs } \\
\text { taking place in the same geography (U.S. or Europe), same Fama-French 12-code industry, and } \\
\text { year as the target firm, and check if this value is lower [higher] than the geography- and } \\
\text { industry-level time series mean. IPO amounts are measured in real December } 2010 \text { U.S. dollars, } \\
\text { after conversion at historical exchange rates. }\end{array}$ \\
\hline Sales Multiple & $\begin{array}{l}\text { Ratio between TEV and latest available yearly sales for the target firm at the time of the LBO. } \\
\text { This variable only takes non-missing values when deal value is known. }\end{array}$ \\
\hline Excess Sales Multiple & $\begin{array}{l}\text { Difference between the target's Sales Multiple and a valuation benchmark constructed as a } \\
\text { follows. For every year, geography (U.S. versus Europe), industry (Fama-French 12-industry } \\
\text { classification) and public status (public or private), we compute the median sales multiple for all } \\
\text { merger transactions with value larger than } 1 \text { million dollars (at constant } 2010 \text { dollars) involving } \\
\text { a majority stake over the previous two years relative to the date of the LBO. }\end{array}$ \\
\hline Ebitda Multiple & $\begin{array}{l}\text { Ratio between TEV and Ebitda for the target firm at the time of the LBO. This variable only } \\
\text { takes non-missing values when deal value is known. }\end{array}$ \\
\hline
\end{tabular}




\begin{tabular}{|c|c|}
\hline Excess Ebitda Multiple & $\begin{array}{l}\text { Difference between the target's Ebitda Multiple and the benchmark, the median Ebitda multiple } \\
\text { for all merger transactions with value larger than } 1 \text { million dollars (at constant } 2010 \text { dollars) } \\
\text { involving a majority stake over the previous two years in the same geography (U.S. versus } \\
\text { Europe), industry (Fama-French 12-industry classification) and public status (public or private) } \\
\text { as the target LBO firm. }\end{array}$ \\
\hline Industry Specialization & $\begin{array}{l}\text { Dummy variable that takes the value } 1 \text { if the PE fund family has done more than one-third of its } \\
\text { past deals in the same industry group as the target's industry. }\end{array}$ \\
\hline Size Specialization & $\begin{array}{l}\text { Set of three indicator variables equal to } 1 \text { if the PE fund family has done more than two-thirds of } \\
\text { its deals in the small (medium) [large] size category, defined as deals with an imputed enterprise } \\
\text { value lower than } 50 \text { million (between } 50 \text { and } 250 \text { million) [more than } 250 \text { million] real } 2010 \\
\text { U.S. dollars. }\end{array}$ \\
\hline Industry Concentration & $\begin{array}{l}\text { Herfindahl index, by geography (U.S. vs. Europe) and year, of public firms with the } 48 \text { Fama- } \\
\text { French industry code as the target firm. }\end{array}$ \\
\hline Asset Liquidity & $\begin{array}{l}\text { Target industry's ratio of the value of corporate transactions (excluding LBOs) to the value of } \\
\text { the total assets of public firms in that industry (Schlingemann, Stulz and Walkling, 2002). }\end{array}$ \\
\hline Past LBO Activity & $\begin{array}{l}\text { Log of the previous } 5 \text { year moving average of LBO activity, measured in billions of real } 2010 \\
\text { U.S. dollars. }\end{array}$ \\
\hline Deal Leverage & $\begin{array}{l}\text { Ratio of Senior Debt to Total Enterprise Value. This ratio is only computed for deals in which } \\
\text { total enterprise value is observed. Senior Debt, defined as the sum of all term debt facilities used } \\
\text { in the deal, is obtained from multiple sources including Capital IQ, DealScan, Dealogic,and } \\
\text { company filings in the case of public-to-private deals. }\end{array}$ \\
\hline Buyer Variables & \\
\hline Variable: & Definition: \\
\hline Dry Powder & $\begin{array}{l}\text { Indicator variable equal to } 1 \text { if the buyer is above median in terms of fund raising and below } \\
\text { median in terms of deal activity. These criteria are computed as follows. First, for each PE fund } \\
\text { family and year, we calculate the aggregate funds raised in the past } 3 \text { years, and the } \\
\text { corresponding median across fund families in that year. Second, for each PE fund family and } \\
\text { year, we compute the aggregate dollar value of all investment made during the past three years, } \\
\text { and its respective median across fund families in that year. All monetary values are measured in } \\
\text { real December } 2010 \text { U.S. dollars, after conversion at historical exchange rates. }\end{array}$ \\
\hline Late Buyer & $\begin{array}{l}\text { Indicator variable equal to } 1 \text { if the buyer's most recent fund at the time of the deal is at the end } \\
\text { of its investment period ( } 4 \text { to } 6 \text { years after inception), and zero otherwise. }\end{array}$ \\
\hline Lack of Reputation & $\begin{array}{l}\text { Indicator variable equal to } 1 \text { if the buyer is not among the PEI Media Top } 50 \text { PE firms, and zero } \\
\text { otherwise. }\end{array}$ \\
\hline Buy Pressure & Sum of variables Dry Powder, Late Buyer, and Lack of Reputation. \\
\hline Affiliated & $\begin{array}{l}\text { Indicator variable equal to } 1 \text { if the buyer is affiliated to a financial institution or government } \\
\text { agency, and zero otherwise. }\end{array}$ \\
\hline Novice & $\begin{array}{l}\text { Indicator variable equal to } 1 \text { if the buyer is a PE fund family with } 3 \text { funds or less under } \\
\text { management at the time of the LBO deal, and zero otherwise. }\end{array}$ \\
\hline \multicolumn{2}{|l|}{ Exit variables } \\
\hline Variable: & Definition: \\
\hline Secondary Exit & Exit route of the LBO is a sale to another PE fund or group of PE funds. \\
\hline Down Exit & $\begin{array}{l}\text { Exit route of the LBO is a sale to existing management, a distressed merger transaction, or } \\
\text { bankruptcy. }\end{array}$ \\
\hline
\end{tabular}




\begin{tabular}{|c|c|}
\hline Trade Sale Exit & Exit route of the LBO is a sale to a corporate buyer. \\
\hline IPO Exit & Exit route of the LBO is a equity listing on public markets. \\
\hline Add-Ons & $\begin{array}{l}\text { Indicator variable equal to } 1 \text { if there were significant acquisitions during the time that the buyer } \\
\text { held the target firm in its portfolio, and zero otherwise. We define acquisitions as significant if } \\
\text { there are three or more acquisitions made by the target company during this period or if they } \\
\text { represent a cumulative dollar value of 5\% or more of the original LBO deal value. }\end{array}$ \\
\hline Late Exit & $\begin{array}{l}\text { Indicator variable equal to } 1 \text { if the three or more years have elapsed since the PE fund family } \\
\text { last exited an LBO deal. }\end{array}$ \\
\hline Late Seller & $\begin{array}{l}\text { Indicator variable equal to } 1 \text { if the sale takes place in years } 9 \text { or } 10 \text { of the PE fund family's } \\
\text { oldest active fund (i.e. less than } 11 \text { years old), and zero otherwise. }\end{array}$ \\
\hline Sell Pressure & Sum of variables Exit Pressure, Late Seller, and Lack of Reputation. \\
\hline Exit HY Spread & $\begin{array}{l}\text { Difference, at the time of the exit from LBO, between the Barclays High Yield Composite index } \\
\text { and the Barclays average corporate AAA corporate bond rate. Only available after } 1987 \text {. }\end{array}$ \\
\hline Exit Cold IPO Market & $\begin{array}{l}\text { Indicator variable equal to } 1 \text { if the IPO market is 'cold' at the time of the LBO exit, and zero } \\
\text { otherwise. }\end{array}$ \\
\hline Novice at Exit & $\begin{array}{l}\text { Indicator variable equal to } 1 \text { if, at the time of exit from the LBO deal, the buyer is a PE fund } \\
\text { family with } 3 \text { funds or less under management, and zero otherwise. }\end{array}$ \\
\hline Exit Sales Multiple & $\begin{array}{l}\text { Ratio between TEV and latest available yearly sales for the target firm at the time of the exit } \\
\text { from the LBO. This variable only takes non-missing values when exit value is known. }\end{array}$ \\
\hline Exit Excess Sales Multiple & $\begin{array}{l}\text { Difference between the target's Sales Multiple and the valuation benchmark at the time of exit } \\
\text { from the LBO. }\end{array}$ \\
\hline Exit Ebitda Multiple & $\begin{array}{l}\text { Ratio between TEV and Ebitda for the target firm at the time of exit from the LBO. This } \\
\text { variable only takes non-missing values when exit value is known. }\end{array}$ \\
\hline $\begin{array}{l}\text { Exit ExcessEbitda } \\
\text { Multiple }\end{array}$ & $\begin{array}{l}\text { Difference between the target'sEbitda Multiple and the valuation benchmark at the time of exit } \\
\text { from the LBO. }\end{array}$ \\
\hline
\end{tabular}




\section{Table A-1}

This table shows the results of a Heckman selection model used to create the imputed Enterprise Values for transactions without deal value information, following Stromberg (2008).Variables specifically constructed for this regression include: Distress, an indicator variable equal to 1 if the LBO target deal is financially distressed; Financial sponsor, an indicator variable equal to 1 if there is at least one Financial Sponsor among buyers; Public Investment Fund, an indicator variable equal to 1 if at least one of the buyers is a listed fund; Independent Private Fund, an indicator variable equal to 1 if at least one of the buyers is an private fund not affiliated with a financial institution; MBO, an indicator variable equal to 1 if there is no evidence of PE involvement; Sponsor $>20$ deals, an indicator variable equal to 1 if the buyer is present in more than 20 deals within the sample period; dummies for geography, where Continental Europe is an indicator variable that takes the value 1 for targets in Belgium, France, Germany, Italy, Luxembourg, Netherlands, Spain, and Switzerland, and Scandinavia is an indicator variable that takes the value 1 for targets in Denmark, Finland, and Sweden; and time dummies for different yearly intervals. All other variables are as described in Appendix B. The outcome equation includes year and industry dummies, where industries are defined using the Fama and French 48industry classification. T-statistics are reported in parentheses and the symbols $* * *, * *,{ }^{*}$ denote statistical significance at respectively the $1 \%, 5 \%$ and $10 \%$ levels.

\begin{tabular}{|c|c|c|c|c|c|c|}
\hline \multirow{3}{*}{$\begin{array}{l}\text { Dependent variable } \\
\text { Private-to-Private }\end{array}$} & \multicolumn{3}{|c|}{$\begin{array}{l}\text { Log of Enterprise Value } \\
\text { (Censored obs.) }\end{array}$} & \multicolumn{3}{|c|}{$\begin{array}{l}\text { Deal Value is Disclosed } \\
\text { (Uncensored obs.) }\end{array}$} \\
\hline & \multicolumn{3}{|c|}{$(1)$} & \multicolumn{3}{|c|}{$(2)$} \\
\hline & -1.506 & (11.69) & $* * *$ & -2.061 & $(30.38)$ & $* * *$ \\
\hline Divisional & -1.335 & $(14.02)$ & $* * *$ & -1.450 & $(21.02)$ & $* * *$ \\
\hline Financial-to-Private & -1.028 & $(7.00)$ & $* * *$ & -1.921 & $(24.80)$ & $* * *$ \\
\hline Secondary & -0.382 & $(3.55)$ & $* * *$ & -1.588 & $(22.21)$ & $* * *$ \\
\hline Distressed & -2.376 & $(17.87)$ & $* * *$ & -1.490 & $(17.67)$ & $* * *$ \\
\hline Financial sponsor & 0.100 & $(0.75)$ & & 0.563 & $(8.75)$ & $* * *$ \\
\hline Public Inv. Fund & -0.086 & $(1.23)$ & & 0.318 & $(8.03)$ & $* * *$ \\
\hline Indep. Private Fund & 0.379 & $(5.62)$ & $* * *$ & -0.146 & $(4.11)$ & $* * *$ \\
\hline MBO & -1.543 & (13.09) & $* * *$ & -0.069 & $(1.18)$ & \\
\hline Sponsor $>20$ deals & 0.890 & $(19.82)$ & $* * *$ & & & \\
\hline Syndicated & 0.126 & $(2.81)$ & $* *$ & 0.204 & $(9.41)$ & $* * *$ \\
\hline U.S. dummy & 0.543 & (10.16) & $* * *$ & -0.453 & (18.84) & $* * *$ \\
\hline Continental Europe dummy & 0.326 & $(4.74)$ & $* * *$ & -0.606 & $(22.32)$ & $* * *$ \\
\hline Scandinavia dummy & 0.084 & $(0.75)$ & & -0.752 & (16.59) & $* * *$ \\
\hline 1970-1984 dummy & & & & 0.555 & $(5.55)$ & $* * *$ \\
\hline 1985-1989 dummy & & & & 0.407 & $(7.21)$ & $* * *$ \\
\hline 1990-1994 dummy & & & & 0.359 & $(7.70)$ & $* * *$ \\
\hline 1995-1999 dummy & & & & 0.359 & (12.89) & $* * *$ \\
\hline 2000-2005 dummy & & & & 0.346 & $(16.40)$ & $* * *$ \\
\hline Heckman's Lambda & -1.459 & $(3.83)$ & $* * *$ & & & \\
\hline Intercept & 4.777 & (11.66) & $* * *$ & 1.206 & $(13.55)$ & \\
\hline Industry dummies & Yes & & & & & \\
\hline Year dummies & Yes & & & & & \\
\hline $\mathrm{N}$ & 8,535 & & & 23,032 & & \\
\hline
\end{tabular}


